\title{
Magnetic Hydrogels from Alkyne/Cobalt Carbonyl-functionalized ABA Triblock Copolymers
}

Bingyin Jiang,,$^{\dagger}$ Wendy L. Hom,,$^{\dagger}$ Xianyin Chen, ${ }^{\dagger}$ Pengqing Yu,,$^{\dagger}$ Laura C. Pavelka, ${ }^{\dagger, \|}$ Kim Kisslinger, ${ }^{\dagger}$ John B. Parise, ${ }^{\dagger}{ }^{\S}$ Surita R. Bhatia, ${ }^{\dagger}$ Robert B. Grubbs ${ }^{* \dagger}$

${ }^{\dagger}$ Department of Chemistry, Stony Brook University, Stony Brook, NY 11794-3400, USA.

$\ddagger$ Center for Functional Nanomaterials, Brookhaven National Laboratory, Upton, NY 11973 , USA.

${ }^{\S}$ Department of Geosciences, Stony Brook University, Stony Brook, NY 11794-2100,USA.

" Current address: Department of Chemistry, McGill University, Montreal, QC, Canada.

\section{Supporting Information}

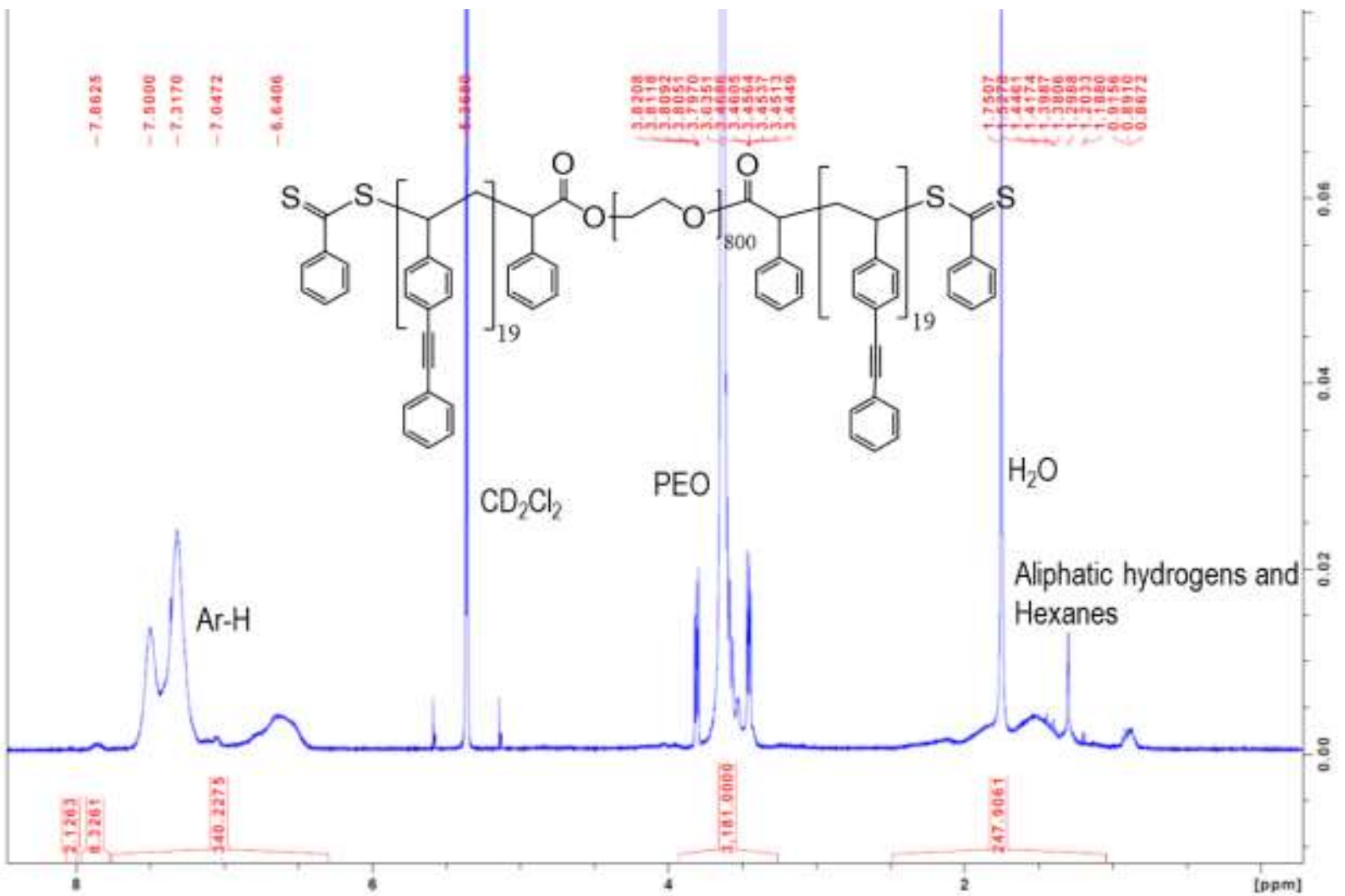

Figure S1. ${ }^{1} \mathrm{H} \mathrm{NMR}\left(400 \mathrm{MHz}, \mathrm{CD}_{2} \mathrm{Cl}_{2}\right)$ spectrum of $\mathrm{ABA}$ triblock copolymer $\mathrm{PES}_{19}-\mathrm{EO}_{800^{-}}$ $\mathrm{PES}_{19}$. 


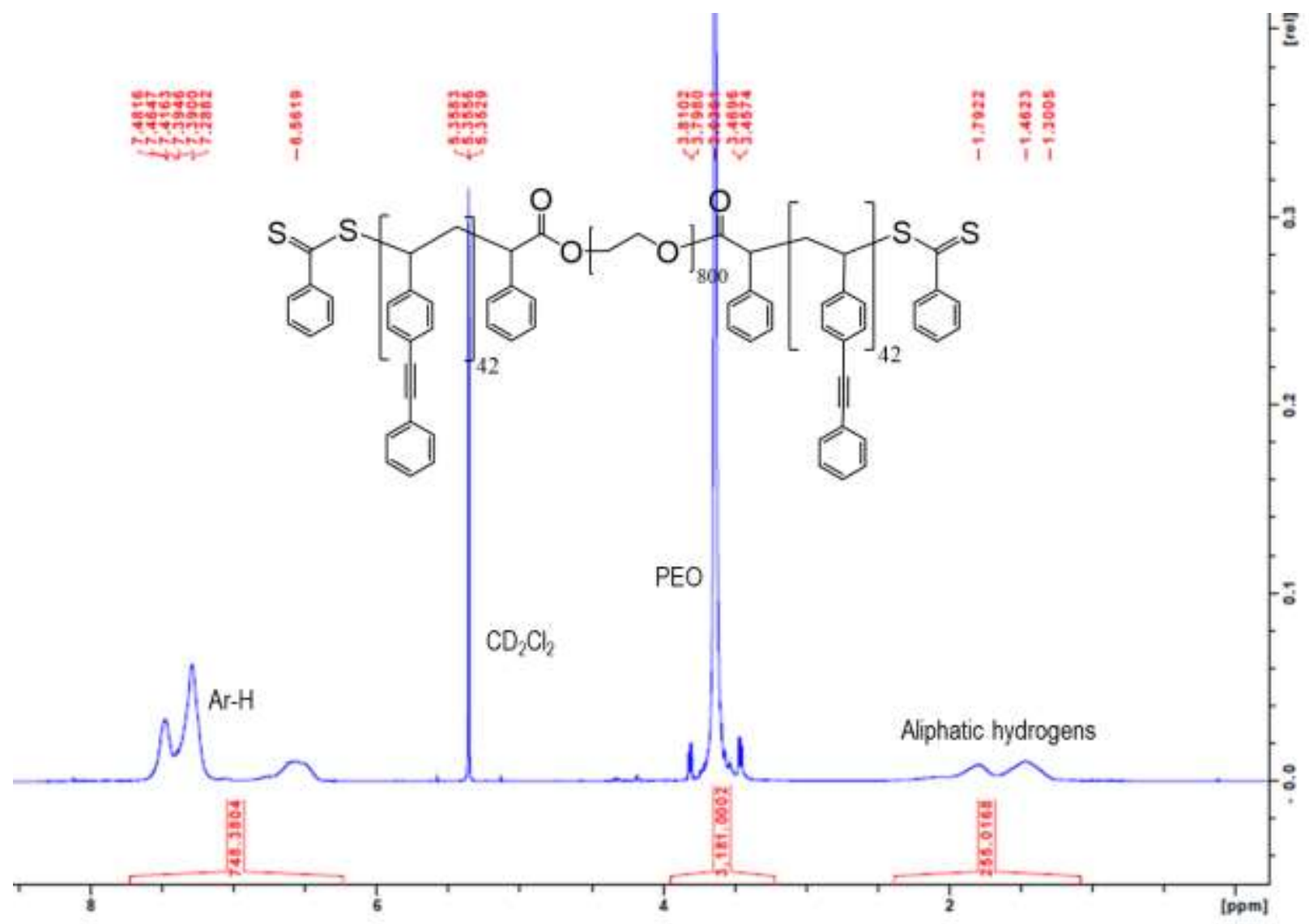

Figure S2. ${ }^{1} \mathrm{H}$ NMR $\left(400 \mathrm{MHz}, \mathrm{CD}_{2} \mathrm{Cl}_{2}\right)$ spectrum of ABA triblock copolymer $\mathrm{PES}_{42}-\mathrm{EO}_{800}-$ $\mathrm{PES}_{42}$. 


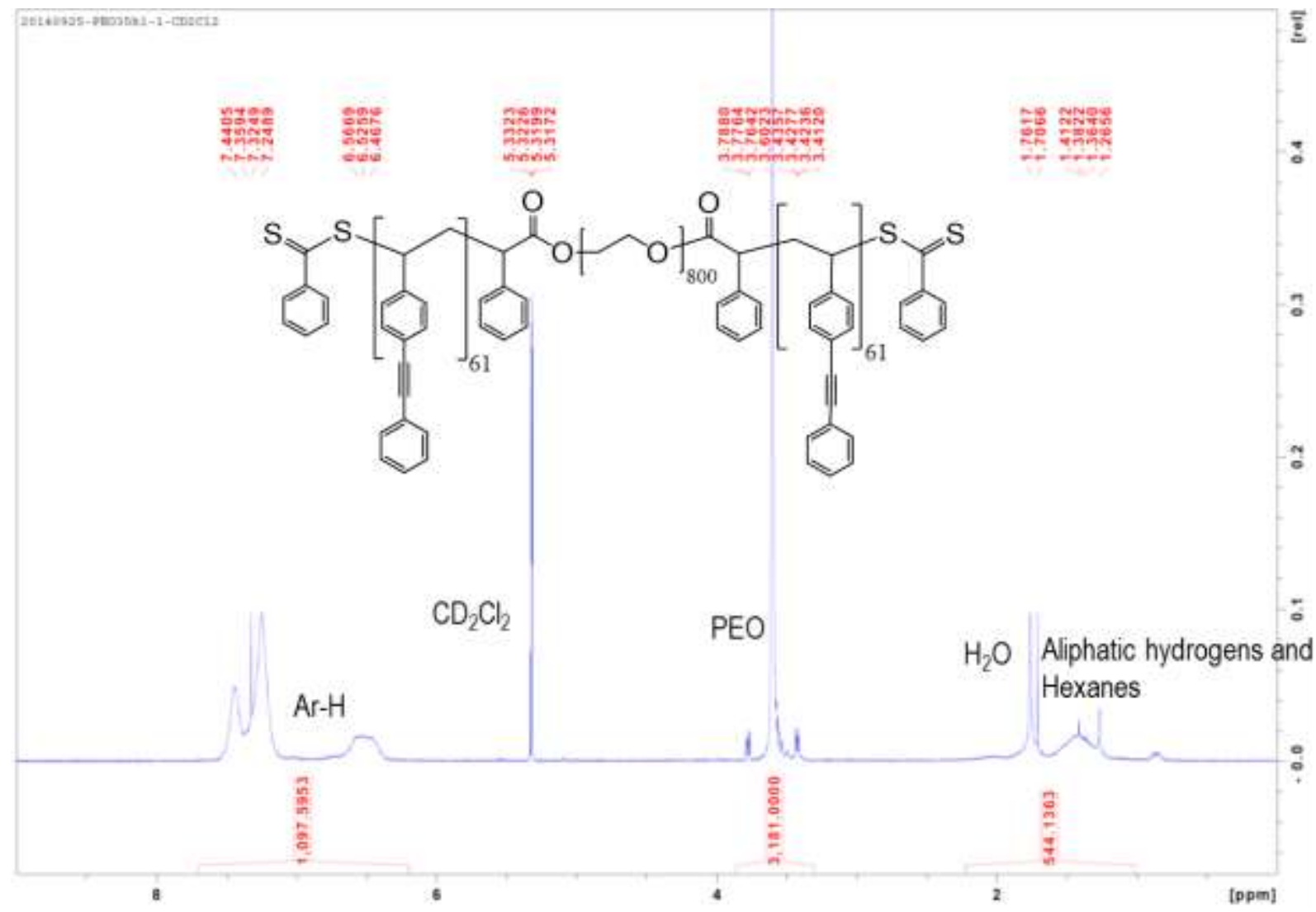

Figure S3. ${ }^{1} \mathrm{H}$ NMR $\left(400 \mathrm{MHz}, \mathrm{CD}_{2} \mathrm{Cl}_{2}\right)$ spectrum of $\mathrm{ABA}$ triblock copolymer $\mathrm{PES}_{61}-\mathrm{EO}_{800^{-}}$ $\mathrm{PES}_{61}$. 


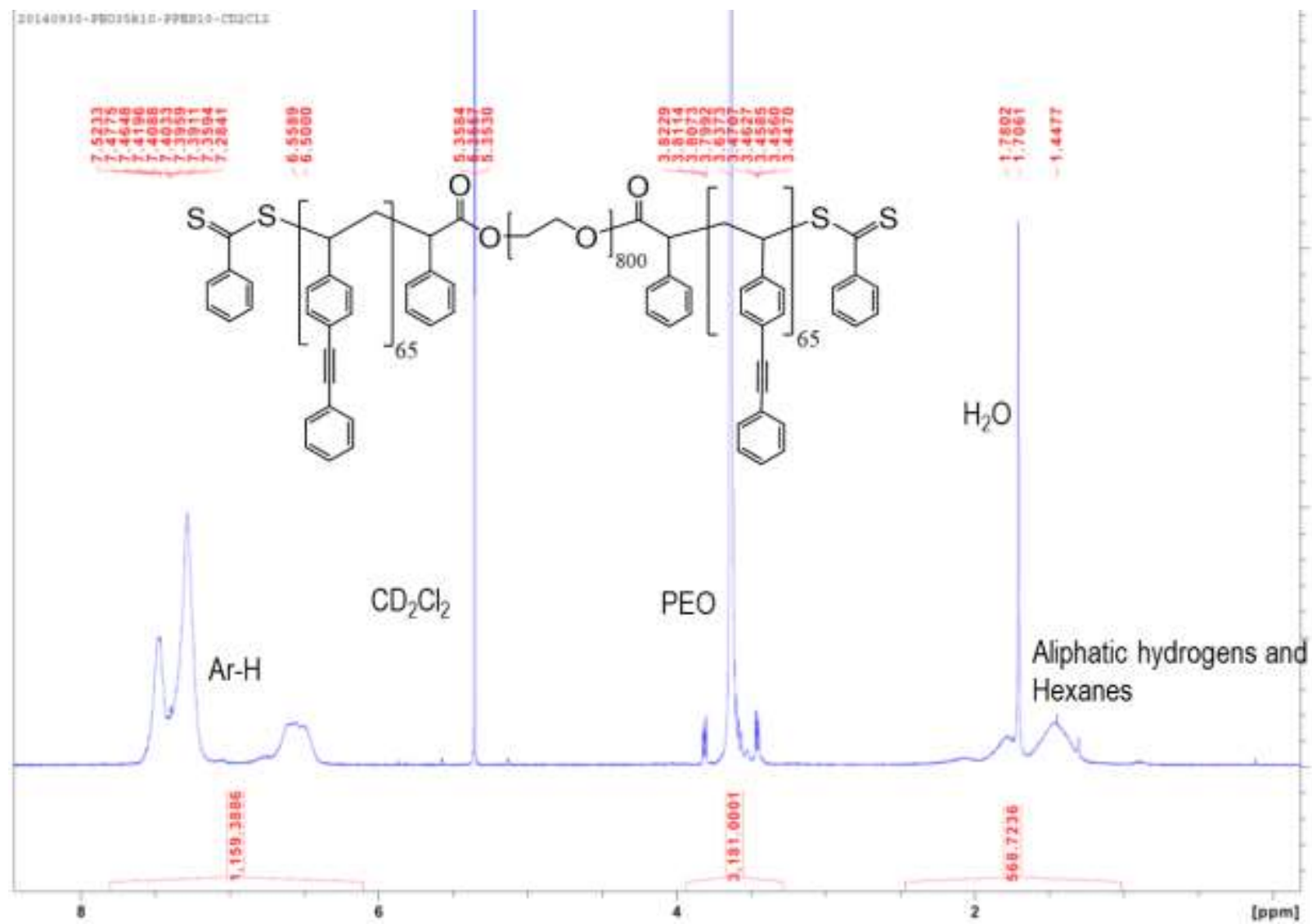

Figure S4. ${ }^{1} \mathrm{H} \mathrm{NMR}\left(400 \mathrm{MHz}, \mathrm{CD}_{2} \mathrm{Cl}_{2}\right)$ spectrum of $\mathrm{ABA}$ triblock copolymer $\mathrm{PES}_{65}-\mathrm{EO}_{800^{-}}$ $\mathrm{PES}_{65}$. 


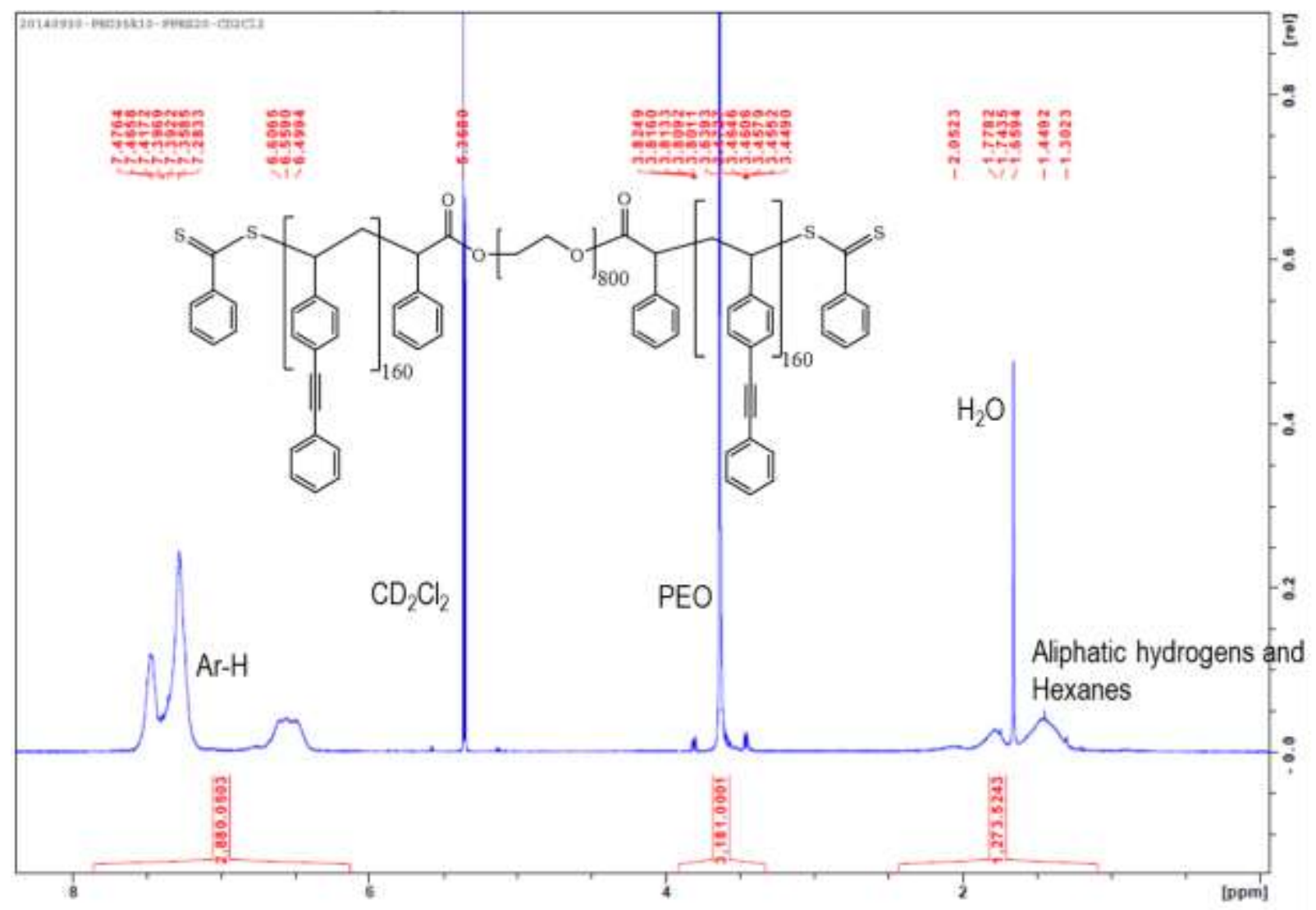

Figure S5. ${ }^{1} \mathrm{H} \mathrm{NMR}\left(400 \mathrm{MHz}, \mathrm{CD}_{2} \mathrm{Cl}_{2}\right)$ spectrum of ABA triblock copolymer $\mathrm{PES}_{160^{-}} \mathrm{EO}_{800^{-}}$ $\mathrm{PES}_{160}$. 


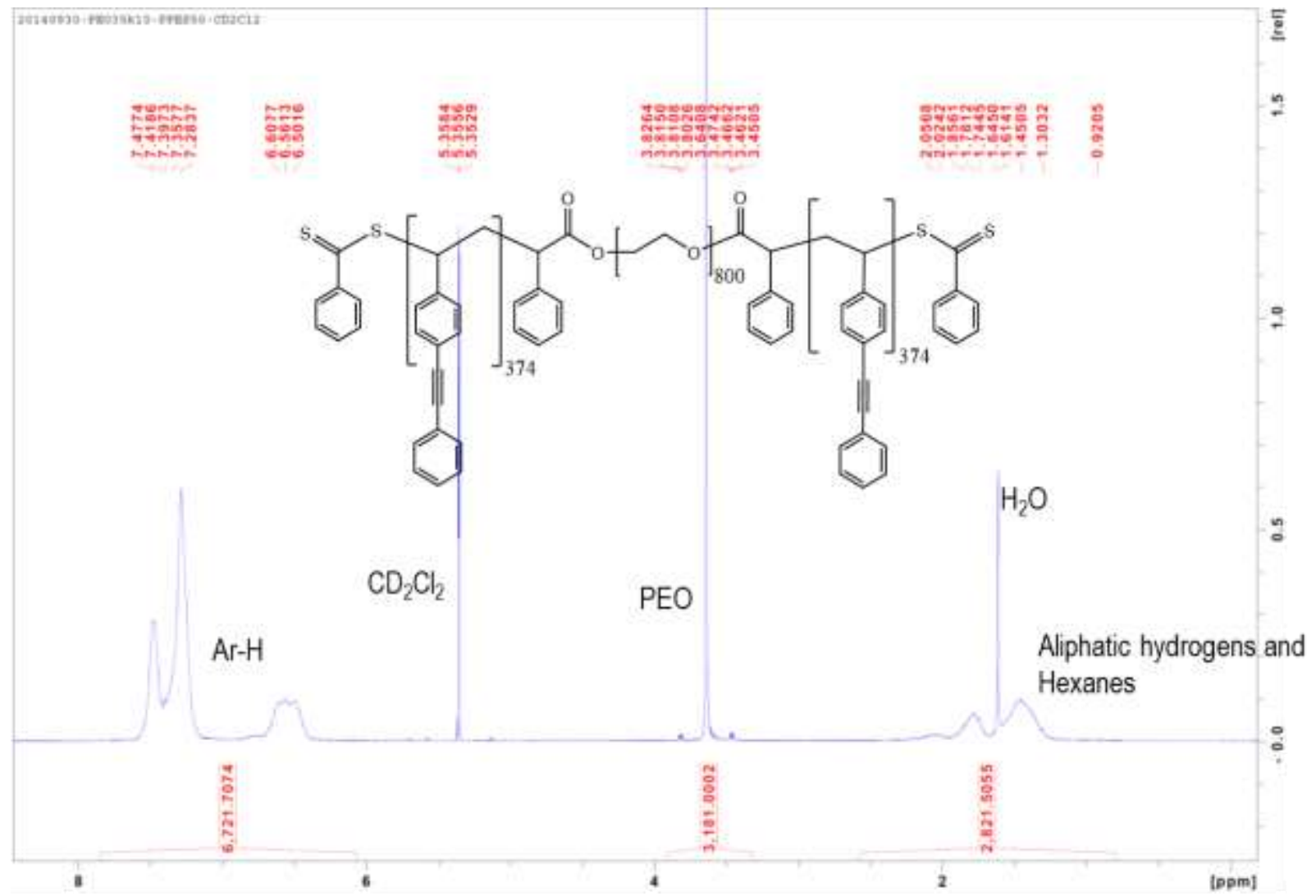

Figure S6. ${ }^{1} \mathrm{H} \mathrm{NMR}\left(400 \mathrm{MHz}, \mathrm{CD}_{2} \mathrm{Cl}_{2}\right)$ spectrum of ABA triblock copolymer $\mathrm{PES}_{374}-\mathrm{EO}_{800^{-}}$ $\mathrm{PES}_{374}$. 


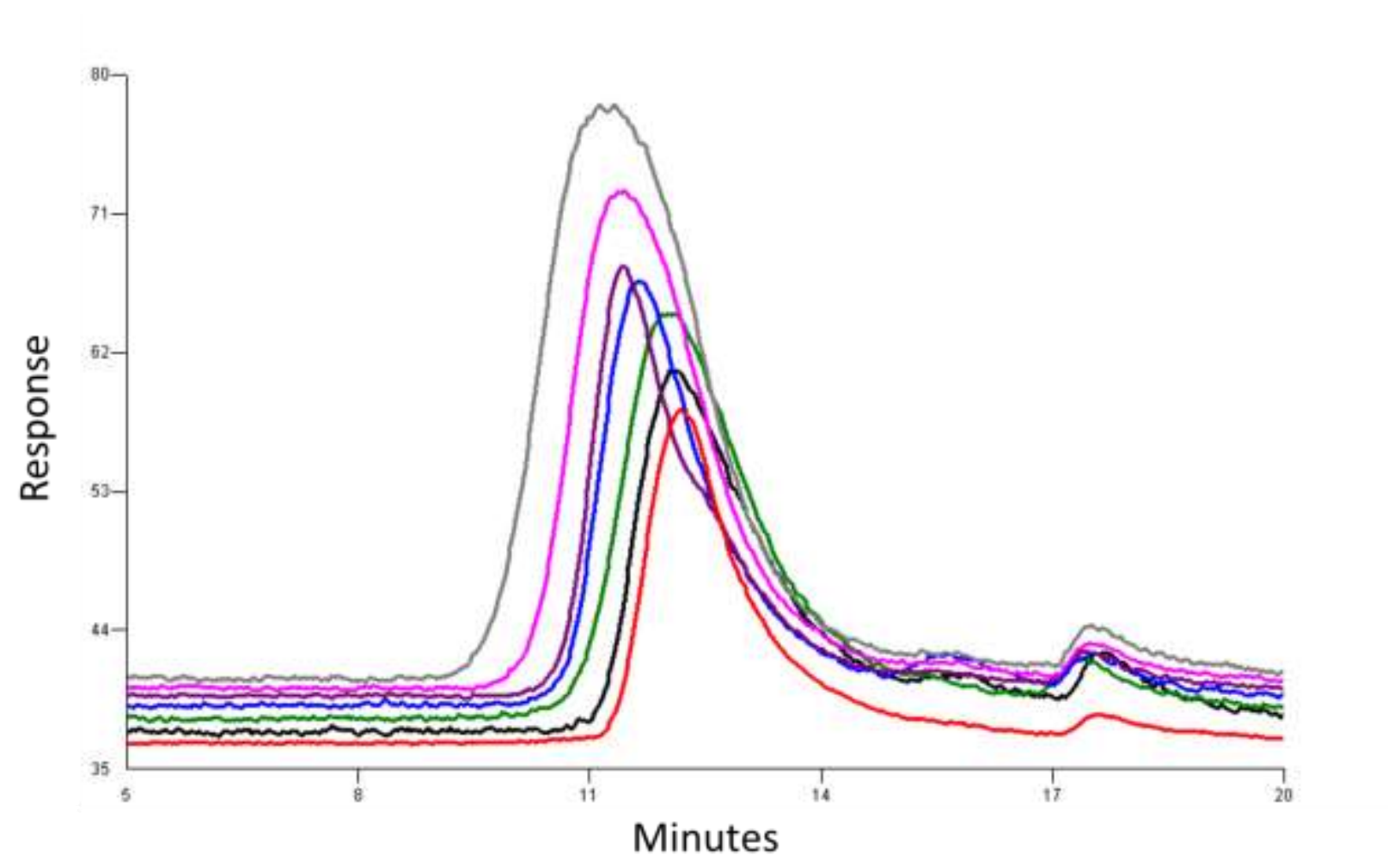

Figure S7. GPC traces of the $\mathrm{PEO}_{800}$ series ABA triblock copolymers. Eluent: THF. Flow rate: $1.0 \mathrm{~mL} / \mathrm{min}$. From bottom to top: CTA-EO $800-\mathrm{CTA}$ (Red), $\mathrm{PES}_{19}-\mathrm{EO}_{800}-\mathrm{PES}_{19}$ (black), $\mathrm{PES}_{42^{-}}$ $\mathrm{EO}_{800}-\mathrm{PES}_{42}$ (green), $\mathrm{PES}_{61}-\mathrm{EO}_{800}-\mathrm{PES}_{61}$ (blue), $\mathrm{PES}_{65}-\mathrm{EO}_{800^{-}} \mathrm{PES}_{65}$ (purple), $\mathrm{PES}_{160^{-}} \mathrm{EO}_{800^{-}}$ $\mathrm{PES}_{160}$ (violet red), $\mathrm{PES}_{374}-\mathrm{EO}_{800}-\mathrm{PES}_{374}$ (grey). 
Table S1. RAFT polymerization conditions for ABA triblock copolymer samples.

\begin{tabular}{cccccccc}
\hline & $\begin{array}{c}\text { mCTA } \\
(\mathrm{mmol})\end{array}$ & $\begin{array}{c}4-\mathrm{PES} \\
(\mathrm{mmol})\end{array}$ & $\begin{array}{c}\text { AIBN } \\
(\mu \mathrm{mol})\end{array}$ & $\begin{array}{c}\text { conversion } \\
\text { by NMR }\end{array}$ & $\begin{array}{c}\text { Time } \\
(\mathrm{h})\end{array}$ & $\begin{array}{c}\mathrm{M}_{n, N M R} \\
(\mathrm{~kg} / \mathrm{mol})^{\mathrm{a}}\end{array}$ & $\bigoplus^{\mathrm{b}}$ \\
\hline $\mathrm{PES}_{19}-\mathrm{EO}_{800}-\mathrm{PES}_{19}$ & 0.0343 & 2.35 & 6.9 & $55 \%$ & 121 & 42.8 & 1.30 \\
$\mathrm{PES}_{42}-\mathrm{EO}_{800}-\mathrm{PES}_{42}$ & 0.0343 & 10.3 & 6.8 & $28 \%$ & 73 & 52.2 & 1.48 \\
$\mathrm{PES}_{61}-\mathrm{EO}_{800}-\mathrm{PES}_{61}^{\mathrm{c}}$ & 0.0286 & 8.4 & 5.7 & $41 \%$ & 186 & 59.9 & 1.39 \\
$\mathrm{PES}_{65}-\mathrm{EO}_{800}-\mathrm{PES}_{65}$ & 0.0229 & 9.79 & 9.1 & $30 \%$ & 72 & 61.3 & 1.49 \\
$\mathrm{PES}_{160}-\mathrm{EO}_{800}-\mathrm{PES}_{160}$ & 0.0143 & 9.79 & 5.7 & $47 \%$ & 167 & 100.4 & 1.56 \\
$\mathrm{PES}_{374}-\mathrm{EO}_{800}-\mathrm{PES}_{374}$ & 0.0086 & 14.7 & 3.4 & $44 \%$ & 167 & 187.5 & 1.75 \\
\hline
\end{tabular}

Unless specified, all polymerizations were run at $90{ }^{\circ} \mathrm{C}$ in toluene at a total reactant concentration of 0.5 $\mathrm{g} / \mathrm{mL}$. ${ }^{\text {a }}$ Calculated from ${ }^{1} \mathrm{H}$ NMR by comparison of the integration of the $-\mathrm{O}-\mathrm{CH}_{2}-\mathrm{CH}_{2}$ peaks $(\mathrm{DP}=800)$ and the aromatic peaks of purified polymers. ${ }^{\mathrm{b}}$ Determined by GPC at $25{ }^{\circ} \mathrm{C}$ using polystyrene standards and THF as eluent. ${ }^{\mathrm{c}}$ Initial reaction temperature was $80{ }^{\circ} \mathrm{C}$ for the first $22 \mathrm{~h}, 90{ }^{\circ} \mathrm{C}$ for the next $68.5 \mathrm{~h}$, then $100{ }^{\circ} \mathrm{C}$ for the final $95.5 \mathrm{~h}$. 


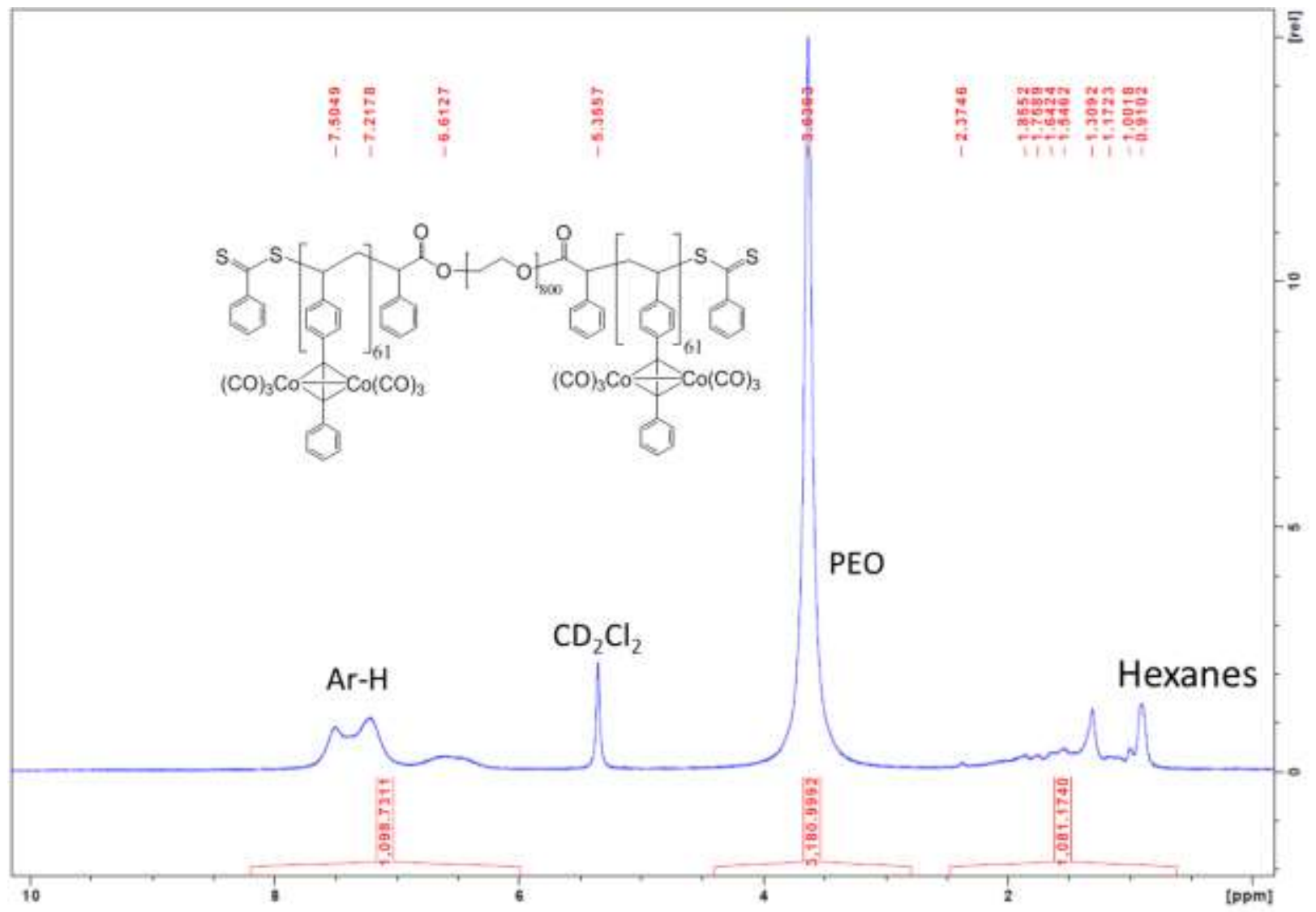

Figure S8. Representative ${ }^{1} \mathrm{H}$ NMR spectrum of triblock copolymer after cobalt addition, sample $\mathrm{PES}_{61}\left[\mathrm{Co}_{2}(\mathrm{CO})_{6}\right]_{52}-\mathrm{EO}_{800}-\mathrm{PES}_{61}\left[\mathrm{Co}_{2}(\mathrm{CO})_{6}\right]_{52}$. 


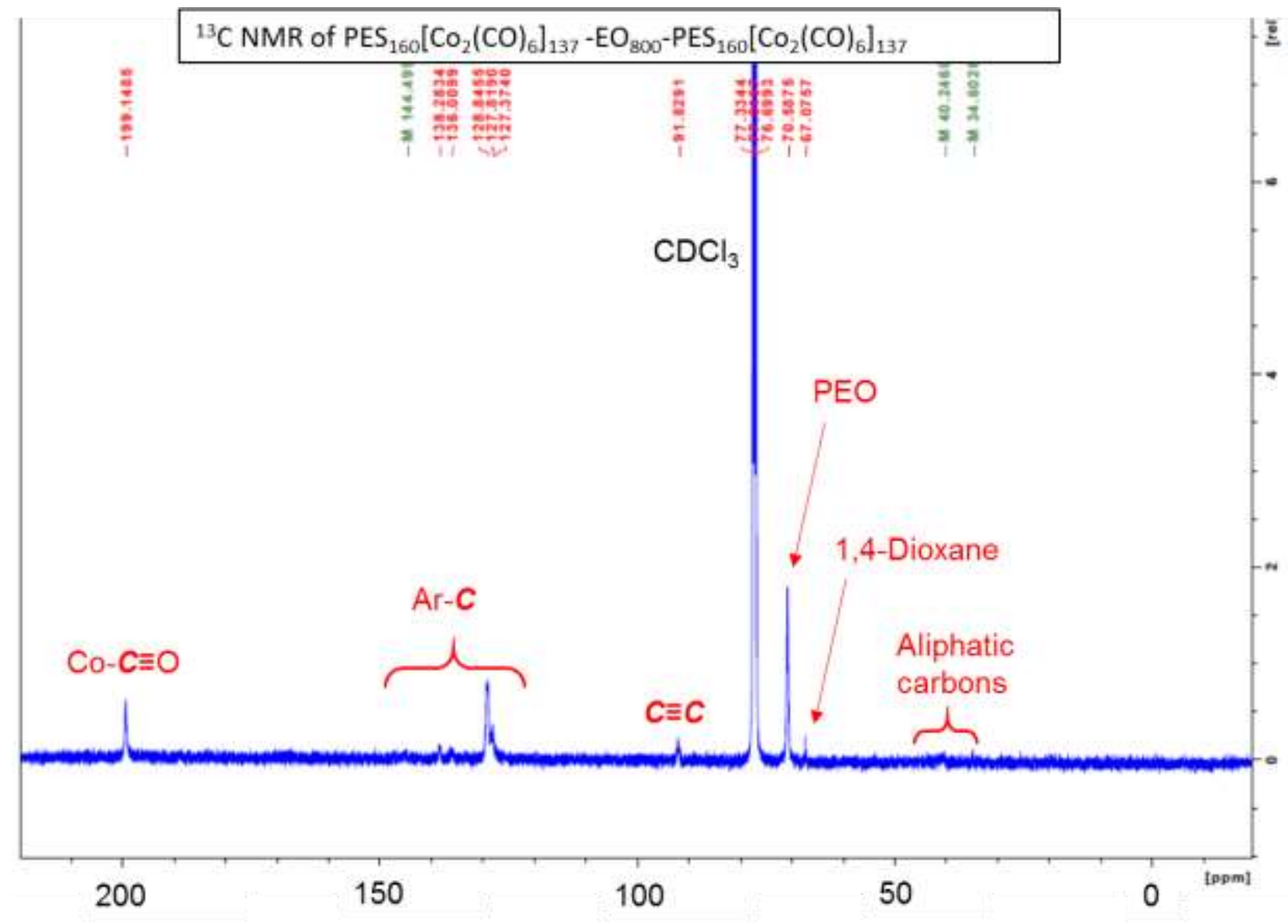

Figure S9. Representative cobalt carbonyl-functionalized triblock copolymer ${ }^{13} \mathrm{C}$ NMR spectrum for sample $\mathrm{PES}_{160}\left[\mathrm{Co}_{2}(\mathrm{CO})_{6}\right]_{137}-\mathrm{EO}_{800}-\mathrm{PES}_{160}\left[\mathrm{Co}_{2}(\mathrm{CO})_{6}\right]_{137}$. 


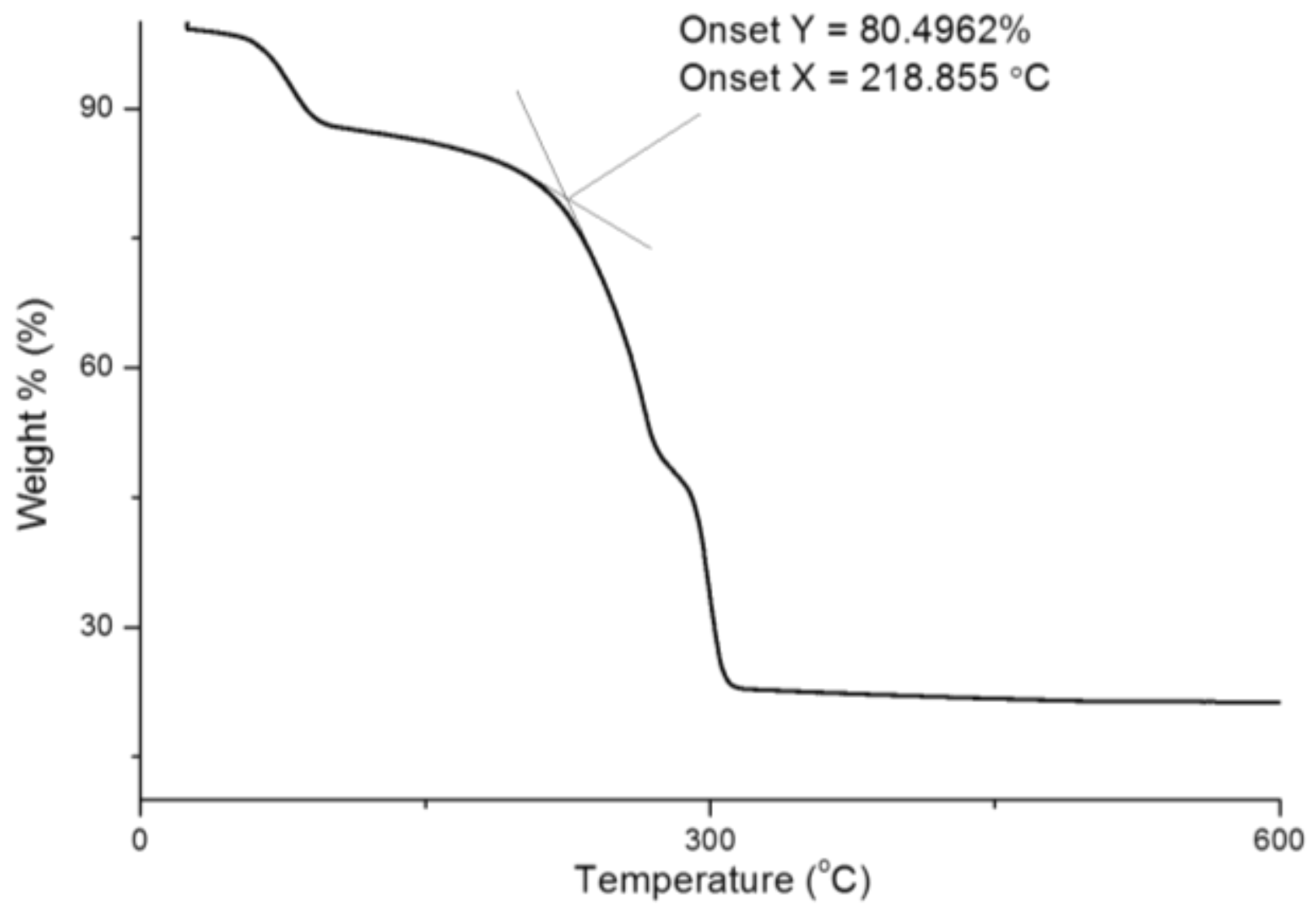

Figure S10. TGA curve of a representative sample: $\mathrm{PES}_{61}\left[\mathrm{Co}_{2}(\mathrm{CO})_{6}\right]_{52}-\mathrm{EO}_{800^{-}}$ $\mathrm{PES}_{61}\left[\mathrm{Co}_{2}(\mathrm{CO})_{6}\right]_{52}$. Heating rate: $1^{\circ} \mathrm{C} / \mathrm{min}, \mathrm{N}_{2}$ atmosphere. 
Table S2. Cobalt addition results

\begin{tabular}{ccc}
\hline Calculated sample composition ${ }^{\mathrm{a}}$ & $\begin{array}{c}\text { \%CO } \\
\text { loss by } \\
\text { TGA }\end{array}$ & $\begin{array}{c}\text { \% Functionalization } \\
\text { of PPES }\end{array}$ \\
\hline $\mathrm{PES}_{19}\left[\mathrm{Co}_{2}(\mathrm{CO})_{6}\right]_{16}-\mathrm{EO}_{800}-\mathrm{PES}_{19}\left[\mathrm{Co}_{2}(\mathrm{CO})_{6}\right]_{16}$ & 10.4 & 84.9 \\
$\mathrm{PES}_{42}\left[\mathrm{Co}_{2}(\mathrm{CO})_{6}\right]_{37}-\mathrm{EO}_{800}-\mathrm{PES}_{42}\left[\mathrm{Co}_{2}(\mathrm{CO})_{6}\right]_{37}$ & 17.0 & 88.6 \\
$\mathrm{PES}_{61}\left[\mathrm{Co}_{2}(\mathrm{CO})_{6}\right]_{52}-\mathrm{EO}_{800}-\mathrm{PES}_{61}\left[\mathrm{Co}_{2}(\mathrm{CO})_{6}\right]_{52}$ & 19.5 & 85.3 \\
$\mathrm{PES}_{65}\left[\mathrm{Co}_{2}(\mathrm{CO})_{6}\right]_{54}-\mathrm{EO}_{800}-\mathrm{PES}_{65}\left[\mathrm{Co}_{2}(\mathrm{CO})_{6}\right]_{54}$ & 19.7 & 83.1 \\
$\mathrm{PES}_{160}\left[\mathrm{Co}_{2}(\mathrm{CO})_{6}\right]_{137}-\mathrm{EO}_{800}-\mathrm{PES}_{160}\left[\mathrm{Co}_{2}(\mathrm{CO})_{6}\right]_{137}$ & 25.8 & 85.9 \\
$\mathrm{PES}_{374}\left[\mathrm{Co}_{2}(\mathrm{CO})_{6}\right]_{309}-\mathrm{EO}_{800}-\mathrm{PES}_{374}\left[\mathrm{Co}_{2}(\mathrm{CO})_{6}\right]_{309}$ & 28.5 & 82.6 \\
\hline Timated percent functionalization of alkyne groups by method described on page 12 of this SI.
\end{tabular}


Calculation of percent functionalization $(\% f)$ of alkyne groups with cobalt carbonyl from TGA data: ${ }^{1}$

For each $\mathrm{PES}_{\mathrm{n}}\left[\mathrm{Co}_{2}(\mathrm{CO})_{6}\right]_{\mathrm{x}}-\mathrm{EO}_{800}-\mathrm{PES}_{\mathrm{n}}\left[\mathrm{Co}_{2}(\mathrm{CO})_{6}\right]_{\mathrm{x}}$ adduct, the weight percent of carbon monoxide $\left(f_{\mathrm{CO}}\right)$ as measured from TGA data can be expressed as:

$f_{C O}=\frac{2 x \times 6 m[\mathrm{CO}]}{M_{n}+m\left[\mathrm{Co}_{2}(\mathrm{CO})_{6}\right] \times 2 x}=\frac{2 x \times 168.06}{M_{n}+285.626 \times 2 x}$

where $x$ is the average number of $\mathrm{Co}_{2}(\mathrm{CO})_{6}$ units attached to each alkyne segment ( $2 x$ in each polymer chain), $m[\mathrm{CO}]$ is the molar mass of $\mathrm{CO}, M_{n}$ is the number-average molecular weight of the PPES-PEO-PPES triblock copolymer determined prior to reaction with cobalt carbonyl, and $m\left[\mathrm{Co}_{2}(\mathrm{CO})_{6}\right]$ is the molar mass of the dicobalt hexacarbonyl moieties bound to the polymer. Solving equation (1) for $x$ allows it to be estimated from the known estimates of $M_{\mathrm{n}}$ and $f_{\mathrm{CO}}$ for each polymer:

$x=\frac{M_{n} \times \%(C O) \times 0.5}{168.06-285.626 \times \%(C O)}$

$\%$ Functionalization is defined as:

$\% f=100 \times x / \mathrm{n}$

Where $\mathrm{n}$ is the average number of PPES units in each PPES segment ( $2 \mathrm{n}$ per polymer chain). 


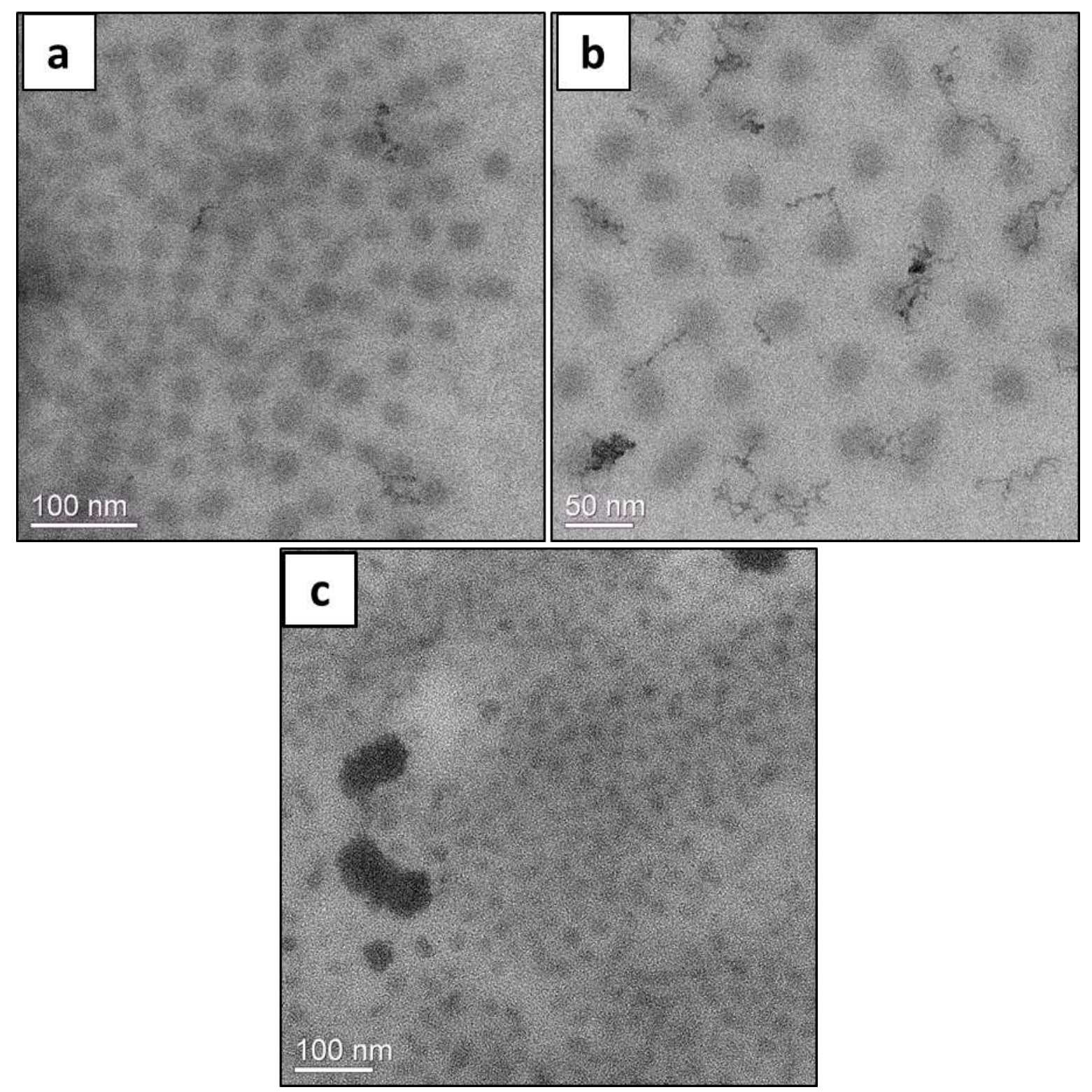

Figure S11. Additional TEM images of sample (PES/Co) ${ }_{19}-\mathrm{EO}_{800}-(\mathrm{PES} / \mathrm{Co})_{19}$. (a) 40,000×; (b) 50,000×; (c) region selected for TEM tomography shown in Video S1. 


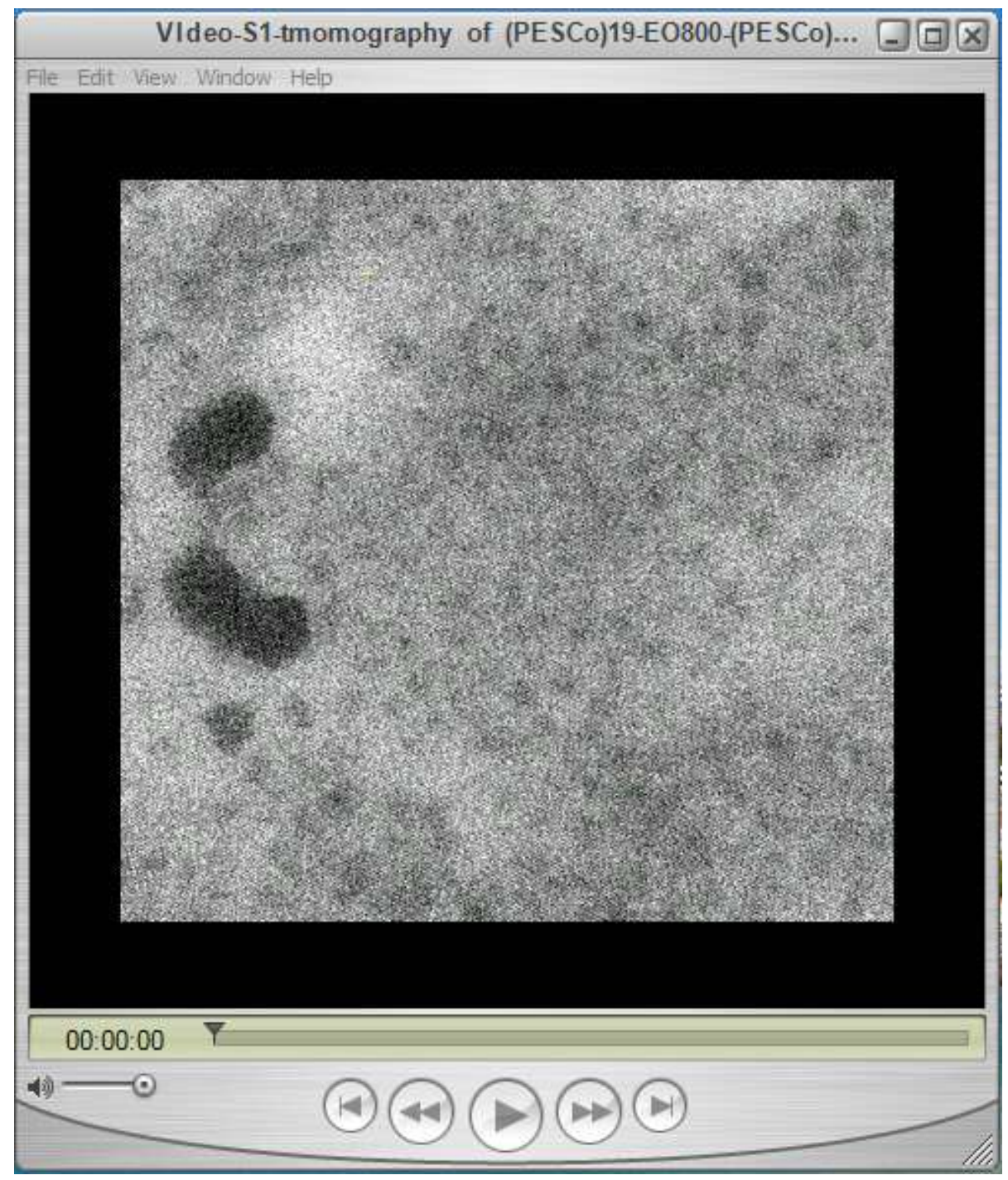

Video S1.Tomography video of sample $(\mathrm{PES} / \mathrm{Co})_{19}-\mathrm{EO}_{800}-(\mathrm{PES} / \mathrm{Co})_{19}$. The image of the same region before tomography investigation is shown in Figure S11c. The full video is available through the ACS website. 


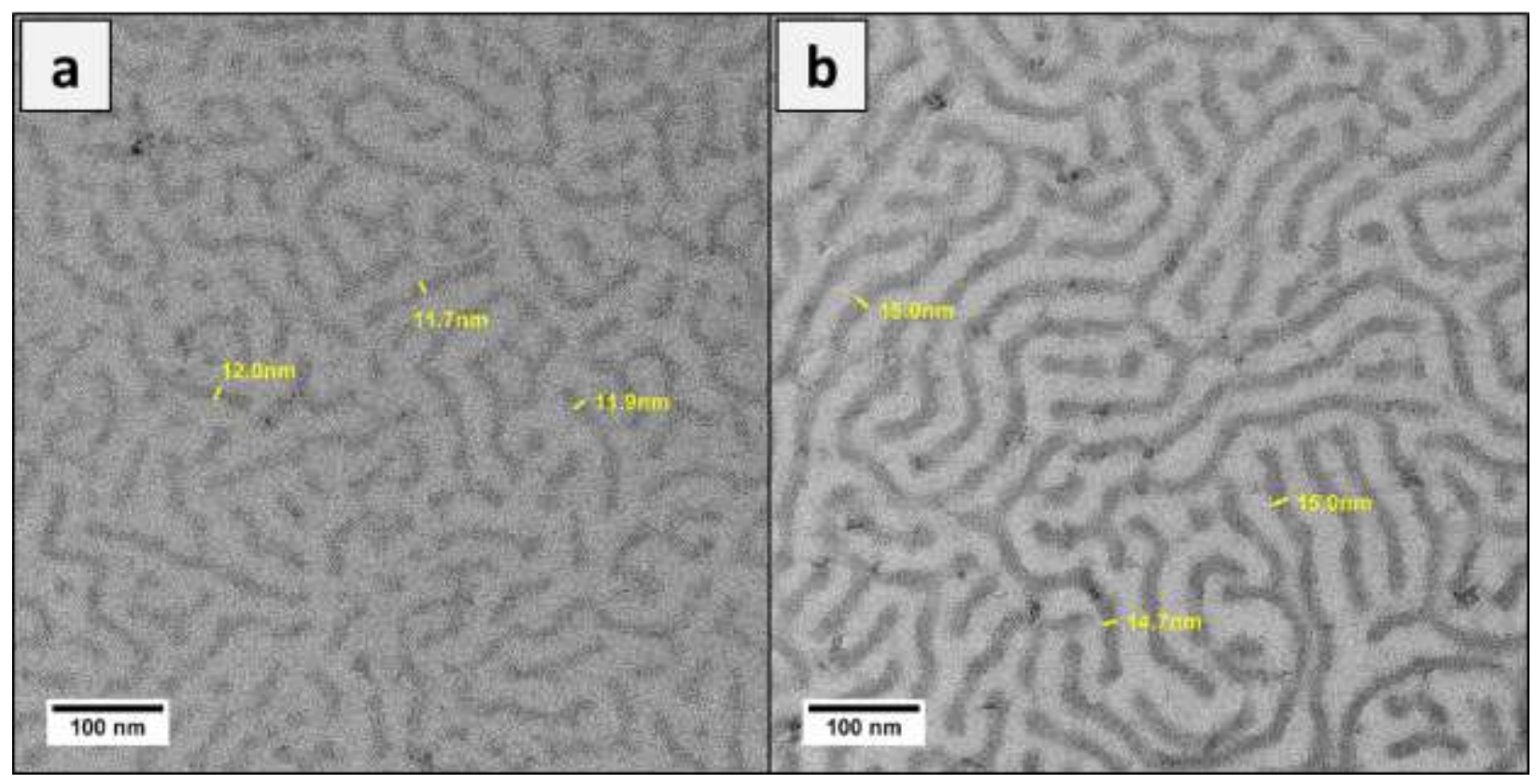

Figure S12. TEM images comparing the domain sizes of (a) $(\mathrm{PES} / \mathrm{Co})_{42}-\mathrm{EO}_{800}(\mathrm{PES} / \mathrm{Co})_{42}$ and (b) $(\mathrm{PES} / \mathrm{Co})_{61}-\mathrm{EO}_{800}-(\mathrm{PES} / \mathrm{Co})_{61}$. 


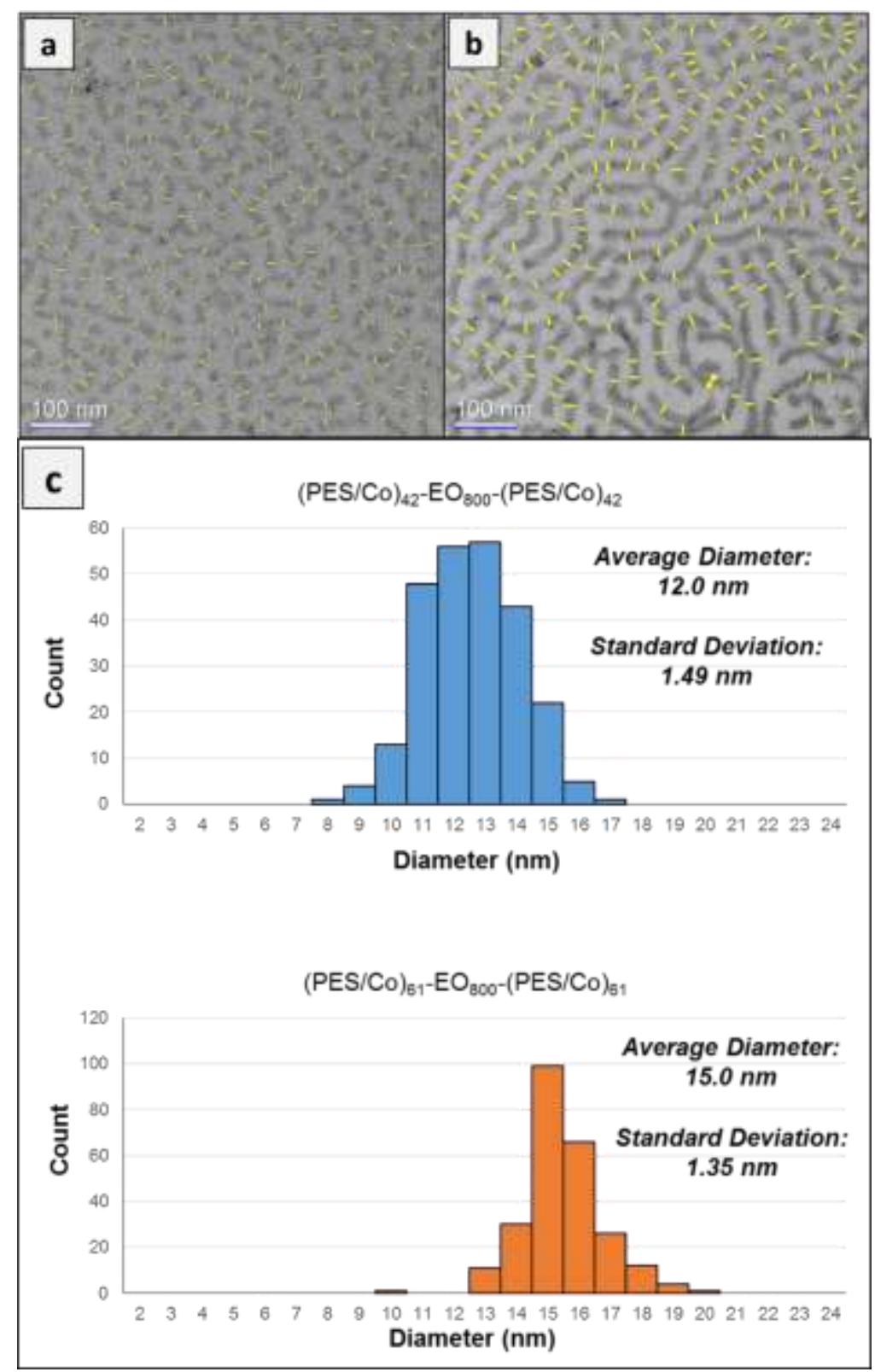

Figure S13. Histograms (c) for cylinder diameter distributions for (a) (PES/Co) ${ }_{42}-\mathrm{EO}_{800^{-}}$ $(\mathrm{PES} / \mathrm{Co})_{42}$ (average diameter $12.0 \mathrm{~nm}$; standard deviation $\left.1.49 \mathrm{~nm}\right)$ and $(\mathrm{b})(\mathrm{PES} / \mathrm{Co})_{61}-\mathrm{EO}_{800^{-}}$ $(\mathrm{PES} / \mathrm{Co})_{61}$ (average diameter $15.0 \mathrm{~nm}$; standard deviation, $1.35 \mathrm{~nm}$ ) (250 points for each image). Diameters were measured by manually taking 250 diameter measurements at different locations in each images, as shown in Figure S13a, b. 


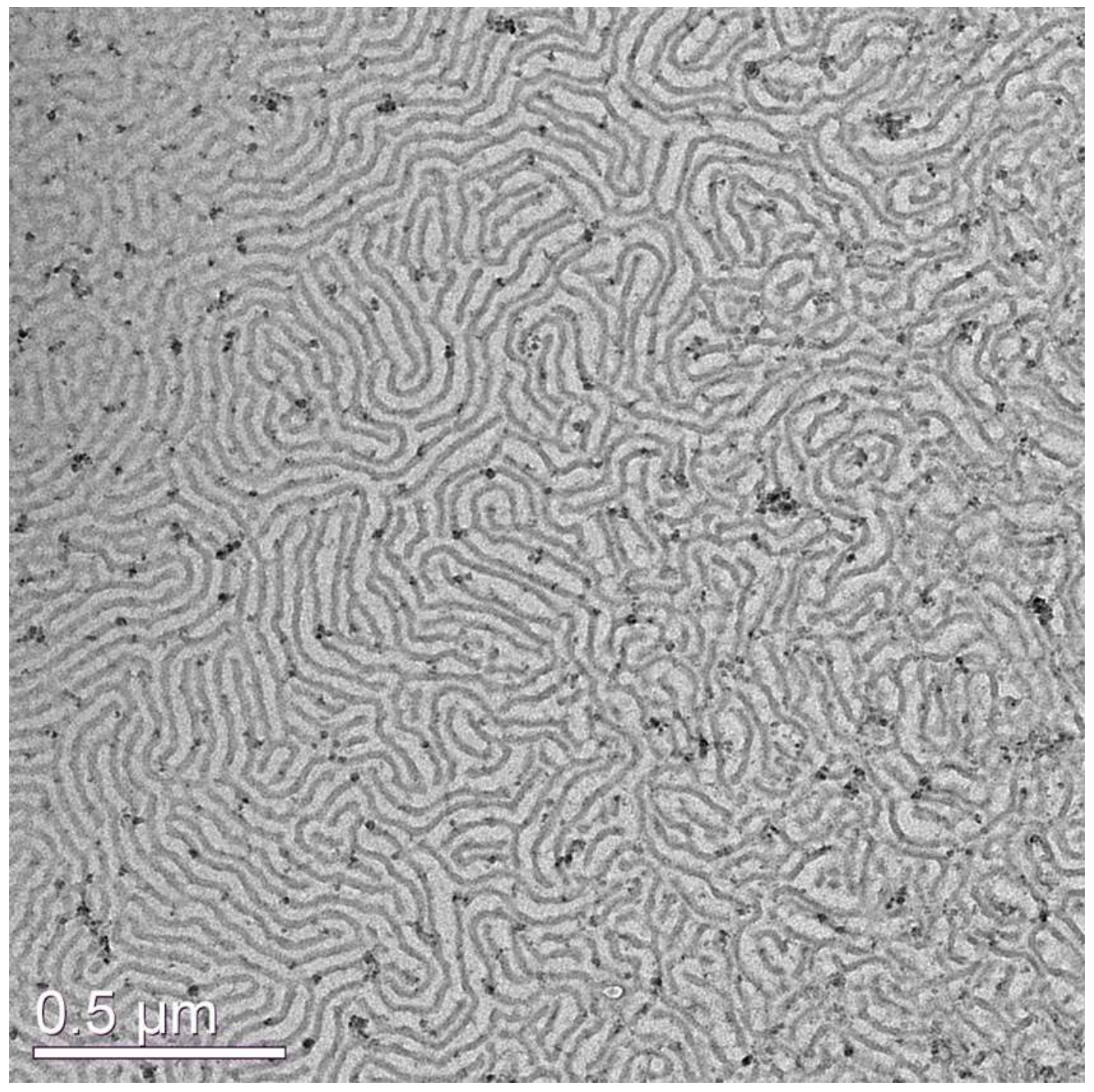

Figure S14. Additional TEM image of sample (PES/Co ${ }_{61}-\mathrm{EO}_{800}-(\mathrm{PES} / \mathrm{Co})_{61}$ 


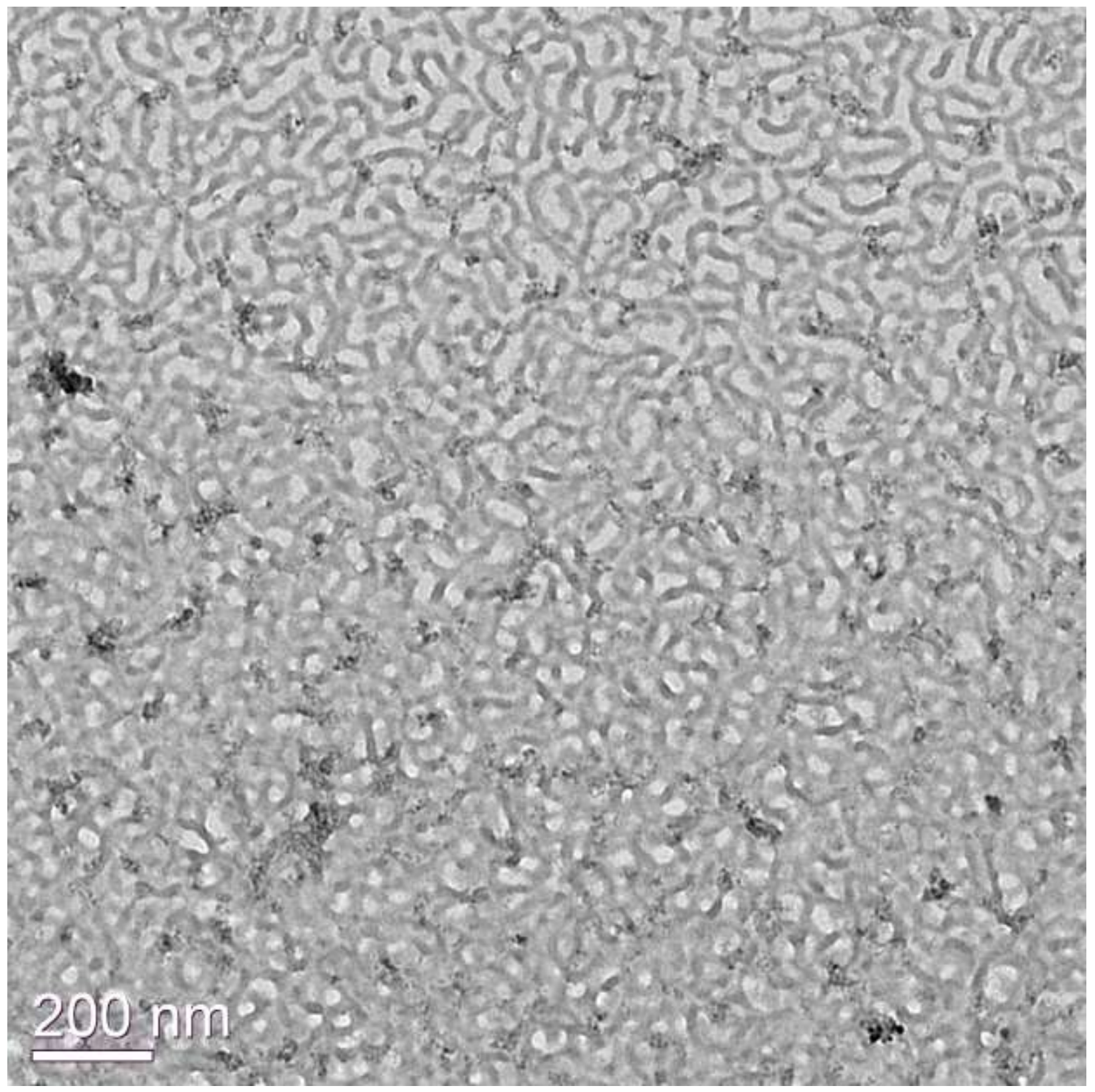

Figure S15. Additional TEM image of sample $(\mathrm{PES} / \mathrm{Co})_{65}-\mathrm{EO}_{800}-(\mathrm{PES} / \mathrm{Co})_{65}$. 


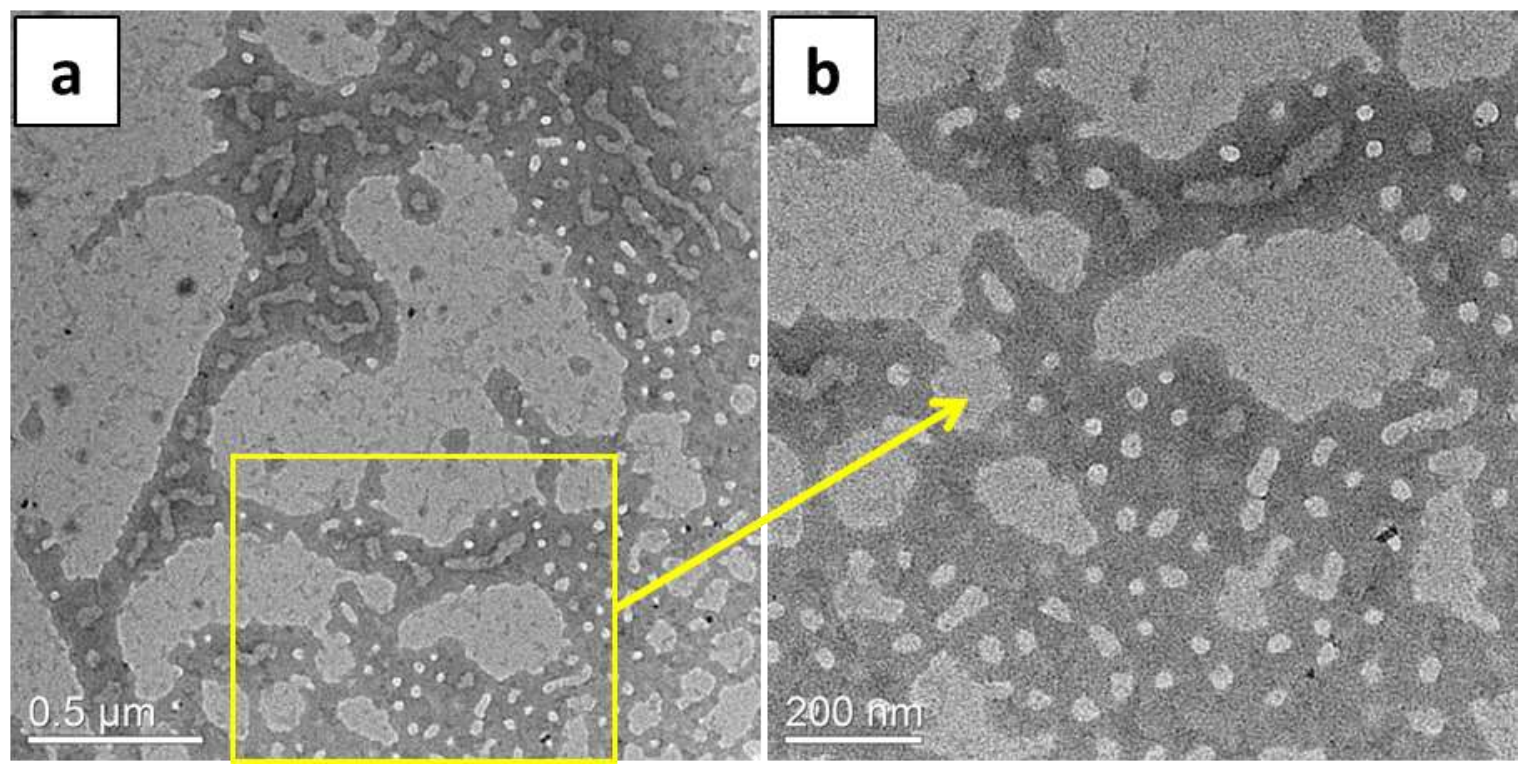

Figure S16. Additional TEM images of sample (PES/Co) ${ }_{374}-\mathrm{EO}_{800}-(\mathrm{PES} / \mathrm{Co})_{374}$. (a) 10,000×; (b) 20,000x. 

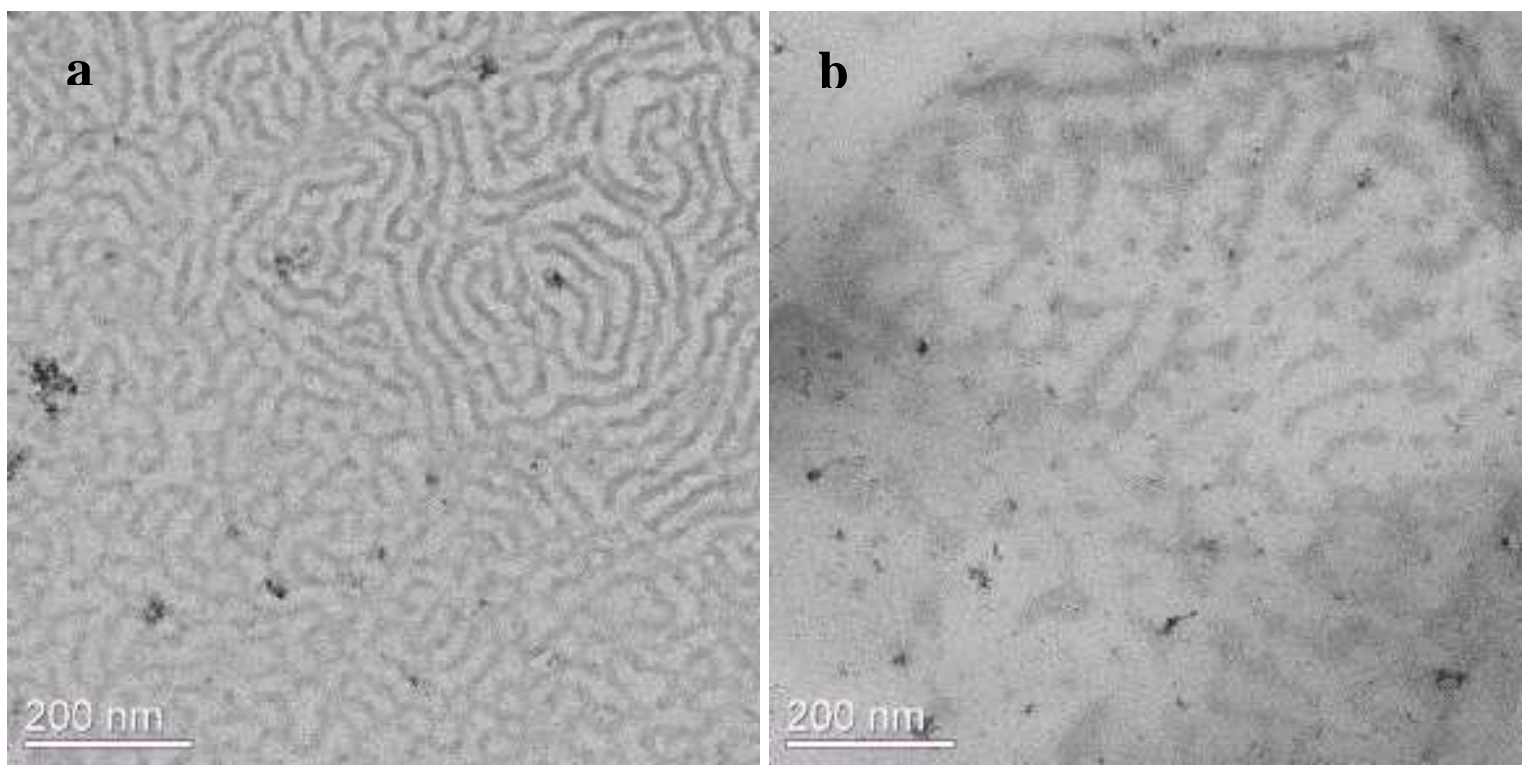

Figure S17. Representative TEM images of sample (PES/Co $)_{42}-\mathrm{EO}_{800}-(\mathrm{PES} / \mathrm{Co})_{42}$ : (a) taken $\sim 12$ hours after sample-preparation; (b) the image of the same grid after heating for $\sim 12 \mathrm{~h}$ at $120^{\circ} \mathrm{C}$ (heating began the same day the first TEM image was acquired) and slowly cooling to room temperature. The observed disruption of morphology was taken as evidence that allowing the sample to crosslink at room temperature prior to heating at $120{ }^{\circ} \mathrm{C}$ was necessary for maintenance of morphology during nanoparticle formation. 


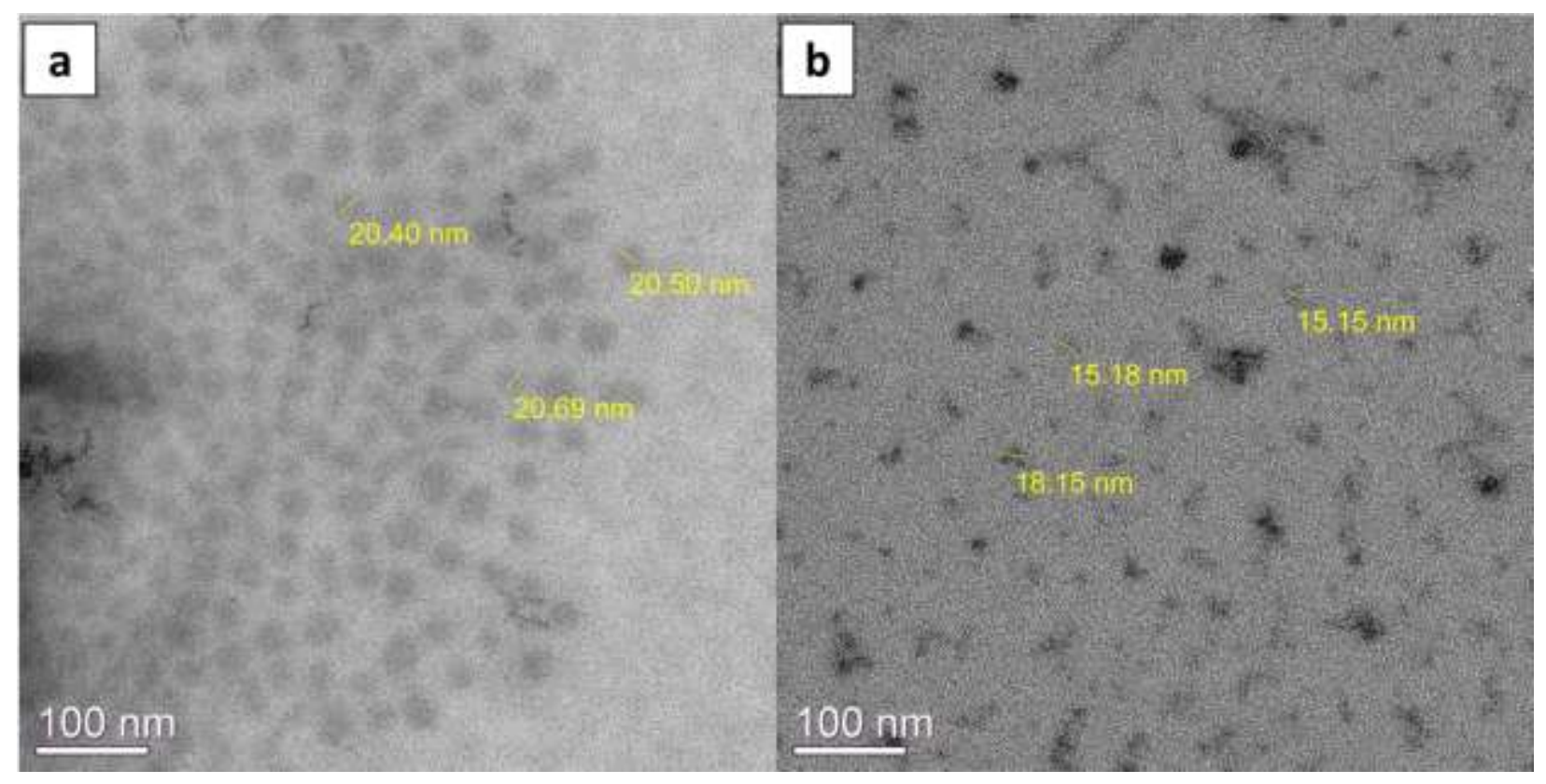

Figure S18. The change of -PPES/Co domain size of sample (PES/Co) ${ }_{19}-\mathrm{EO}_{800}-(\mathrm{PES} / \mathrm{Co})_{19}$, (a) before heating and (b) after heating. 


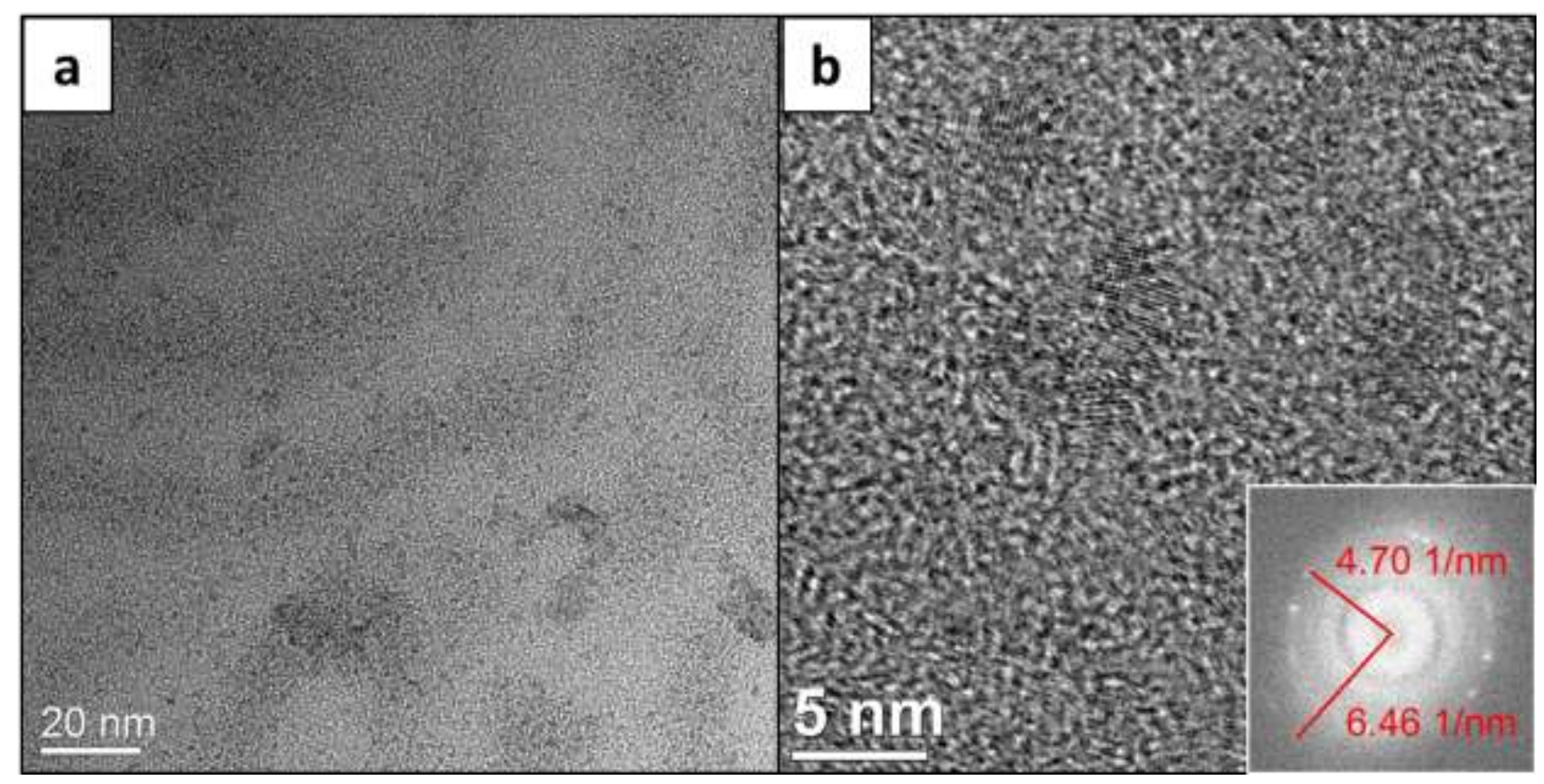

Figure S19. TEM images of sample (PES/Co) ${ }_{42}-\mathrm{EO}_{800}-(\mathrm{PES} / \mathrm{Co})_{42}$ after heating. (a) $120,000 \times$ magnification and (b) 800,000× magnification. Inset of (b): FFT of image b. 


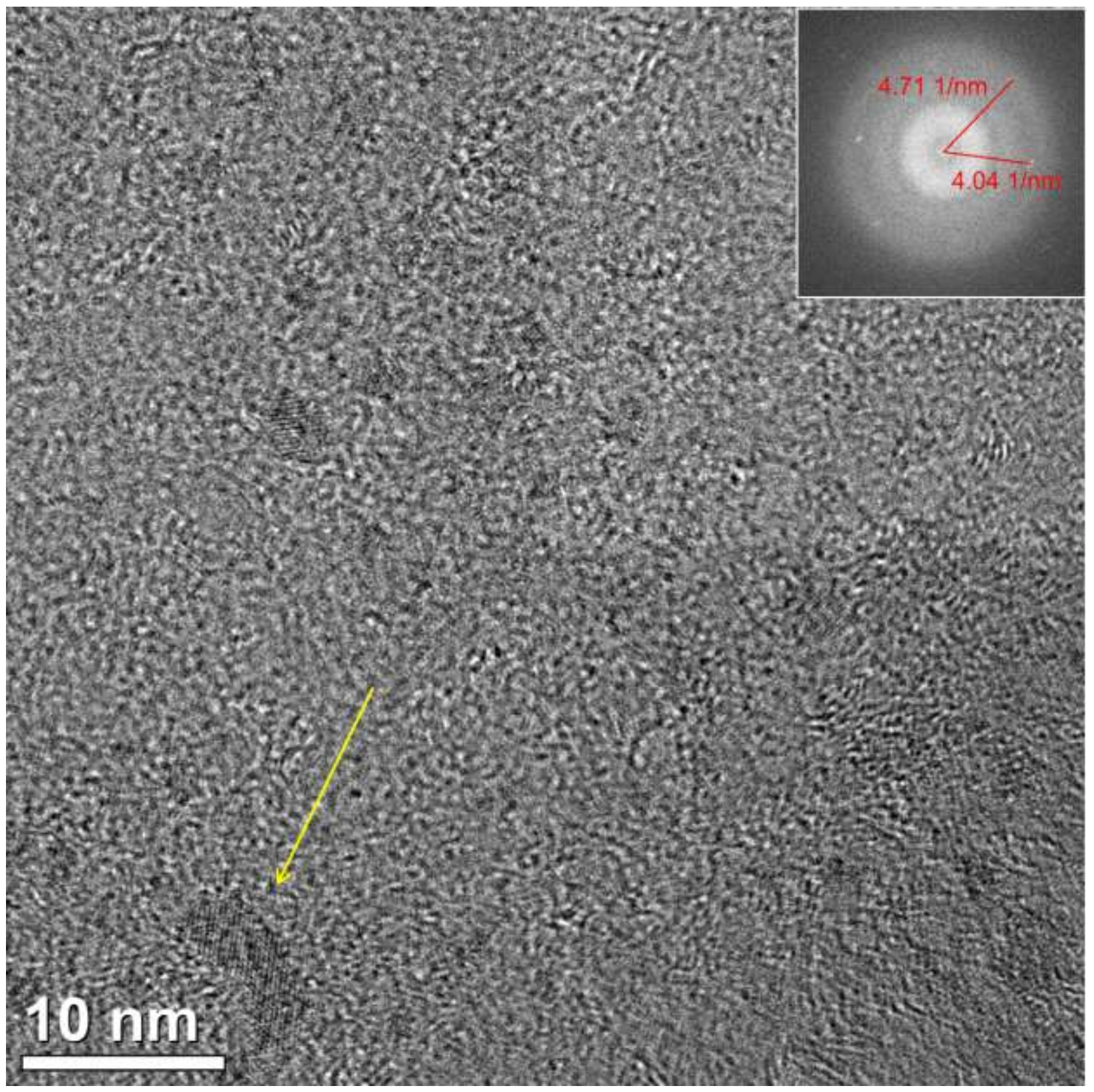

Figure S20. TEM images of sample (PES/Co $)_{65}-\mathrm{EO}_{800}-(\mathrm{PES} / \mathrm{Co})_{65}$ after heating at 400,000× magnification. The arrow indicates a particle with dimensions larger than $5 \mathrm{~nm}$. Inset: FFT of this image. 


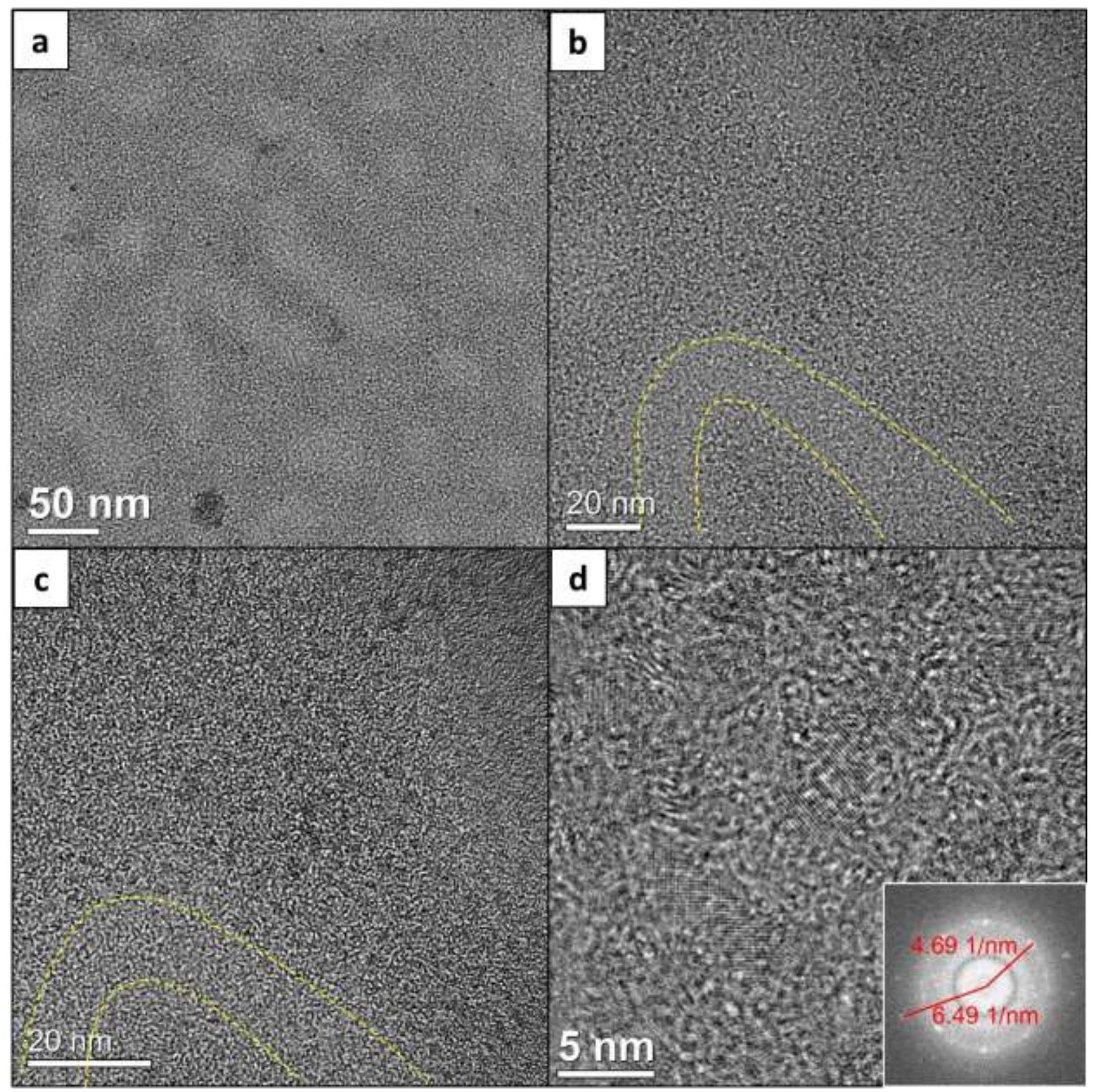

Figure S21. TEM images of sample (PES/Co) ${ }_{160}-\mathrm{EO}_{800}-(\mathrm{PES} / \mathrm{Co})_{160}$ after heating. (a) 60,000x magnification; (b) 150,000× magnification; (c) 250,000× magnification; (d) 800,000× magnification. Inset of d: FFT of image $d$. 


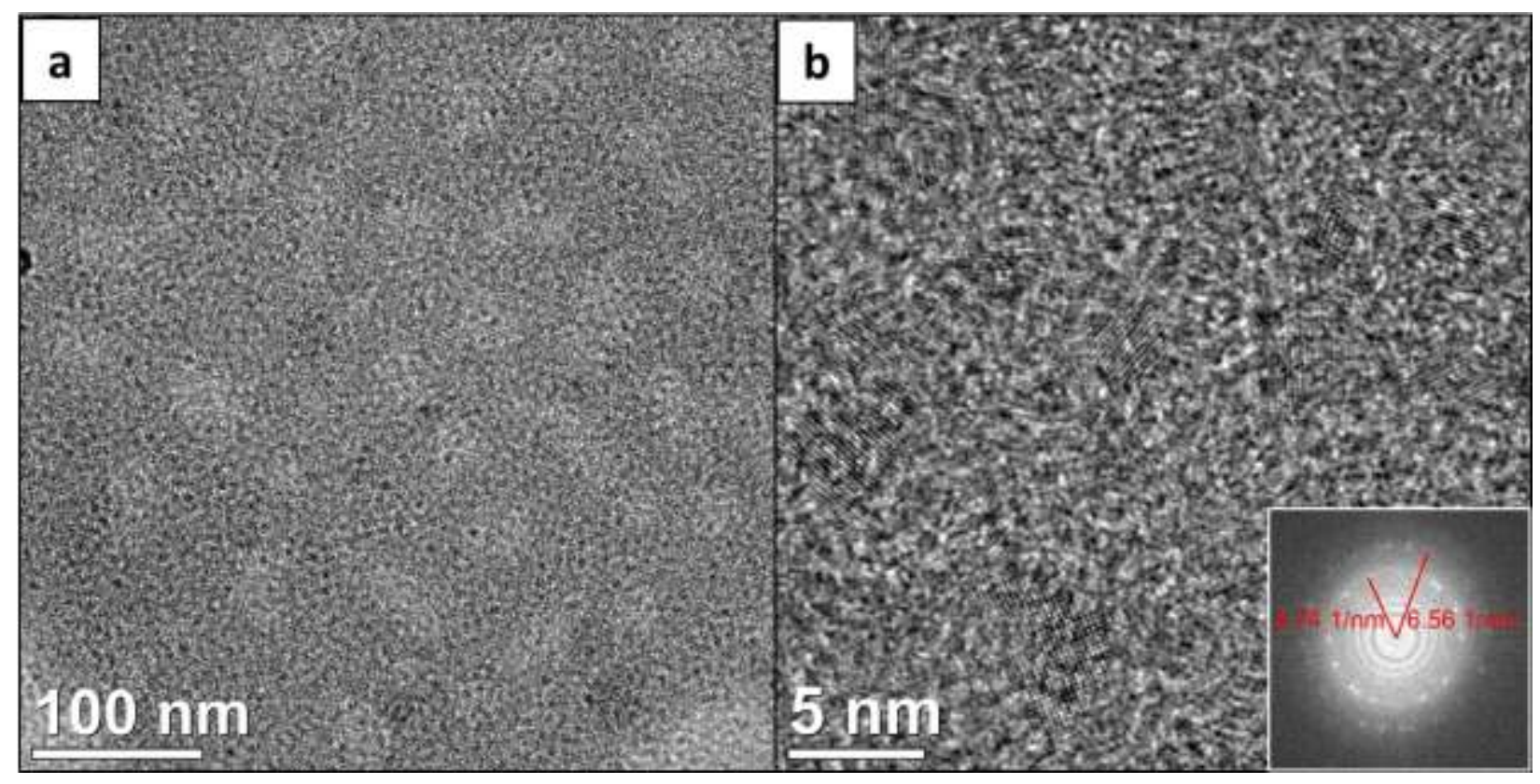

Figure S22. TEM images of sample (PES/Co $)_{374}-\mathrm{EO}_{800}-(\mathrm{PES} / \mathrm{Co})_{374}$ after heating. (a) 50,000x magnification; (b) 800,000× magnification. Inset of b: FFT of image b. 


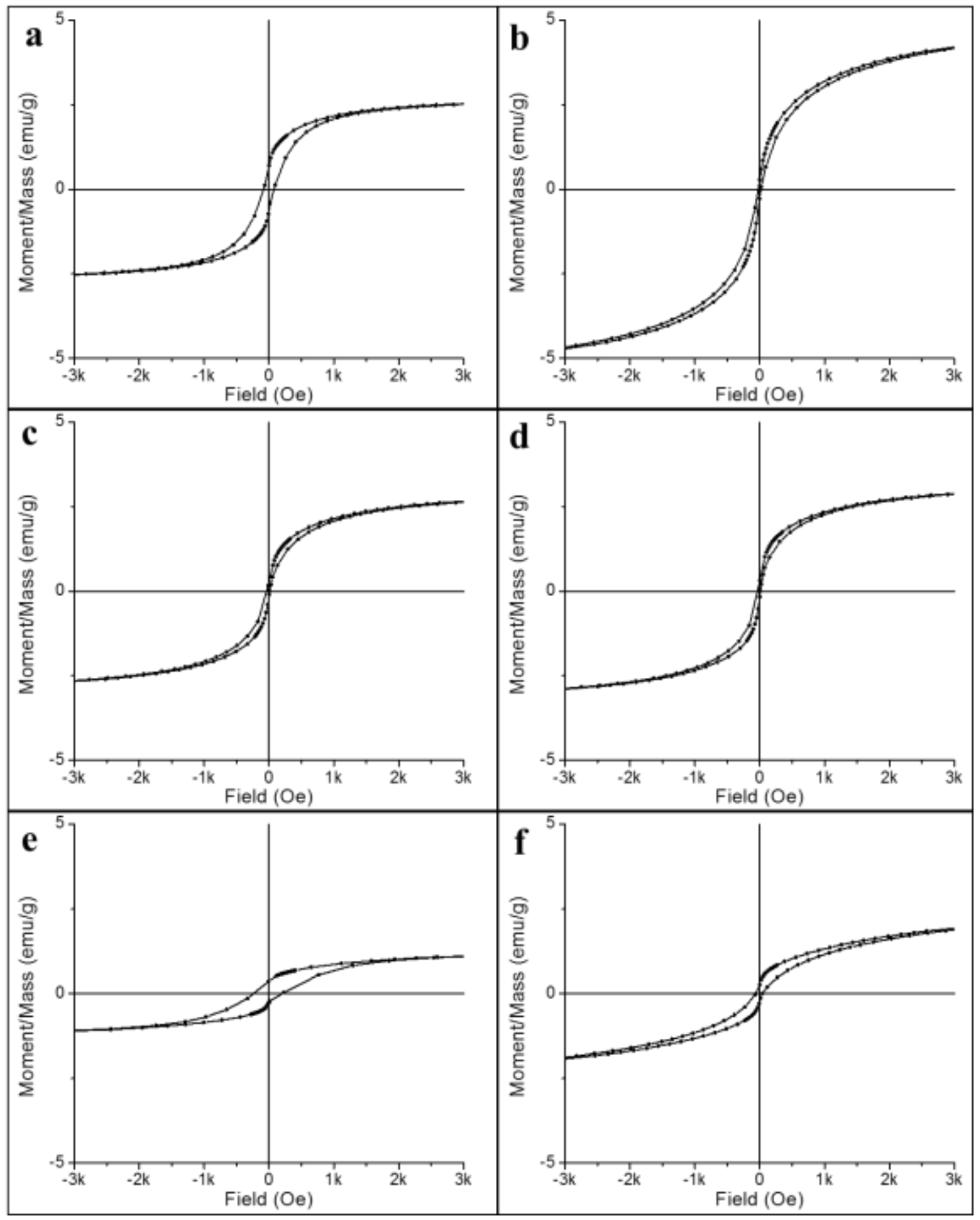

Figure S23. The magnetization curves of samples after heating at $120{ }^{\circ} \mathrm{C}$ for $24 \mathrm{~h}$ : (a) $(\mathrm{PES} / \mathrm{Co})_{19}-\mathrm{EO}_{800}-(\mathrm{PES} / \mathrm{Co})_{19}$; (b) $(\mathrm{PES} / \mathrm{Co})_{42}-\mathrm{EO}_{800}-(\mathrm{PES} / \mathrm{Co})_{42}$; (c) $(\mathrm{PES} / \mathrm{Co})_{61}-\mathrm{EO}_{800^{-}}$ $(\mathrm{PES} / \mathrm{Co})_{61}$; (d) $(\mathrm{PES} / \mathrm{Co})_{65}-\mathrm{EO}_{800}-(\mathrm{PES} / \mathrm{Co})_{65}$; (e) (PES/Co $)_{160}-\mathrm{EO}_{800}-(\mathrm{PES} / \mathrm{Co})_{160}$; (f) $(\mathrm{PES} / \mathrm{Co})_{374}-\mathrm{EO}_{800}-(\mathrm{PES} / \mathrm{Co})_{374}$. 
Table S3. Saturation magnetization $\left(M_{\mathrm{s}}\right)$, remanence $\left(M_{\mathrm{r}}\right)$, and coercivity for copolymer/Co composites ${ }^{\mathrm{a}}$.

\begin{tabular}{|c|c|c|c|}
\hline Sample & $M_{\mathrm{s}}(\mathrm{emu} / \mathrm{g} \mathrm{Co})^{\mathrm{b}}$ & $M_{\mathrm{r}}(\mathrm{emu} / \mathrm{g} \mathrm{Co})^{\mathrm{b}}$ & $\begin{array}{l}\text { Coercivity } \\
\text { (Oe) }\end{array}$ \\
\hline$(\mathrm{PES} / \mathrm{Co})_{19}-\mathrm{EO}_{800}-(\mathrm{PES} / \mathrm{Co})_{19}$ & 36.4 & 7.94 & 81.2 \\
\hline$(\mathrm{PES} / \mathrm{Co})_{42}-\mathrm{EO}_{800}-(\mathrm{PES} / \mathrm{Co})_{42}$ & 37.5 & 1.80 & 21.9 \\
\hline$(\mathrm{PES} / \mathrm{Co})_{61}-\mathrm{EO}_{800^{-}}(\mathrm{PES} / \mathrm{Co})_{61}$ & 19.0 & 1.27 & 25.2 \\
\hline$(\mathrm{PES} / \mathrm{Co})_{65}-\mathrm{EO}_{800^{-}}(\mathrm{PES} / \mathrm{Co})_{65}$ & 20.5 & 1.42 & 24.5 \\
\hline$(\mathrm{PES} / \mathrm{Co})_{160}-\mathrm{EO}_{800}-(\mathrm{PES} / \mathrm{Co})_{160}$ & 5.85 & 1.29 & 220.8 \\
\hline$(\mathrm{PES} / \mathrm{Co})_{374}-\mathrm{EO}_{800^{-}}(\mathrm{PES} / \mathrm{Co})_{374}$ & 9.47 & 0.901 & 52.2 \\
\hline
\end{tabular}




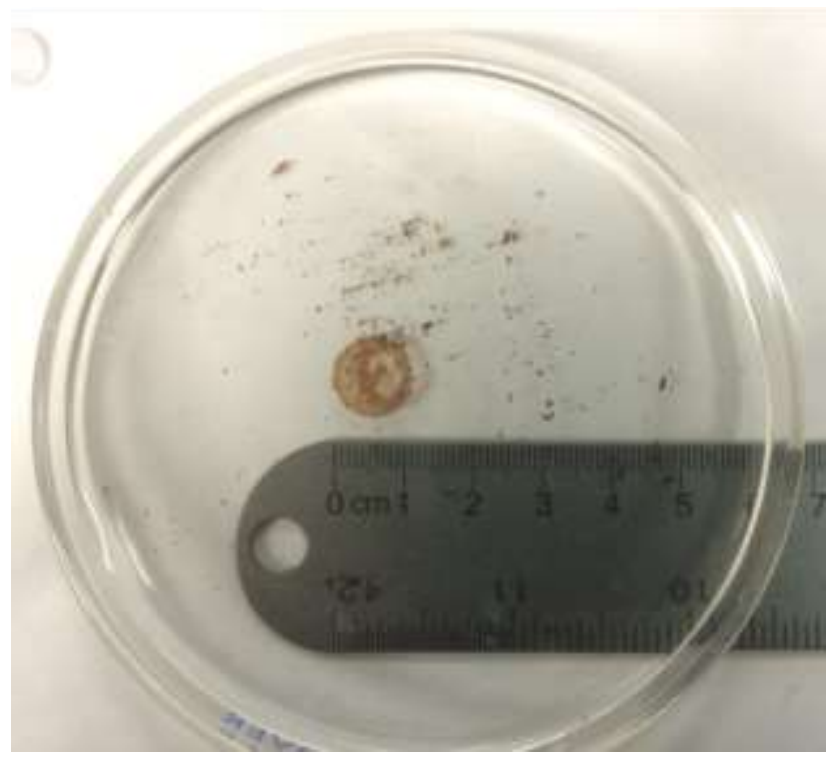

Figure S24. Heated sample $\left(120^{\circ} \mathrm{C}, 24 \text { hours, vacuum) of (PES/Co }\right)_{160}-\mathrm{EO}_{800}-(\mathrm{PES} / \mathrm{Co})_{160}$ loses integrity upon swelling in water.

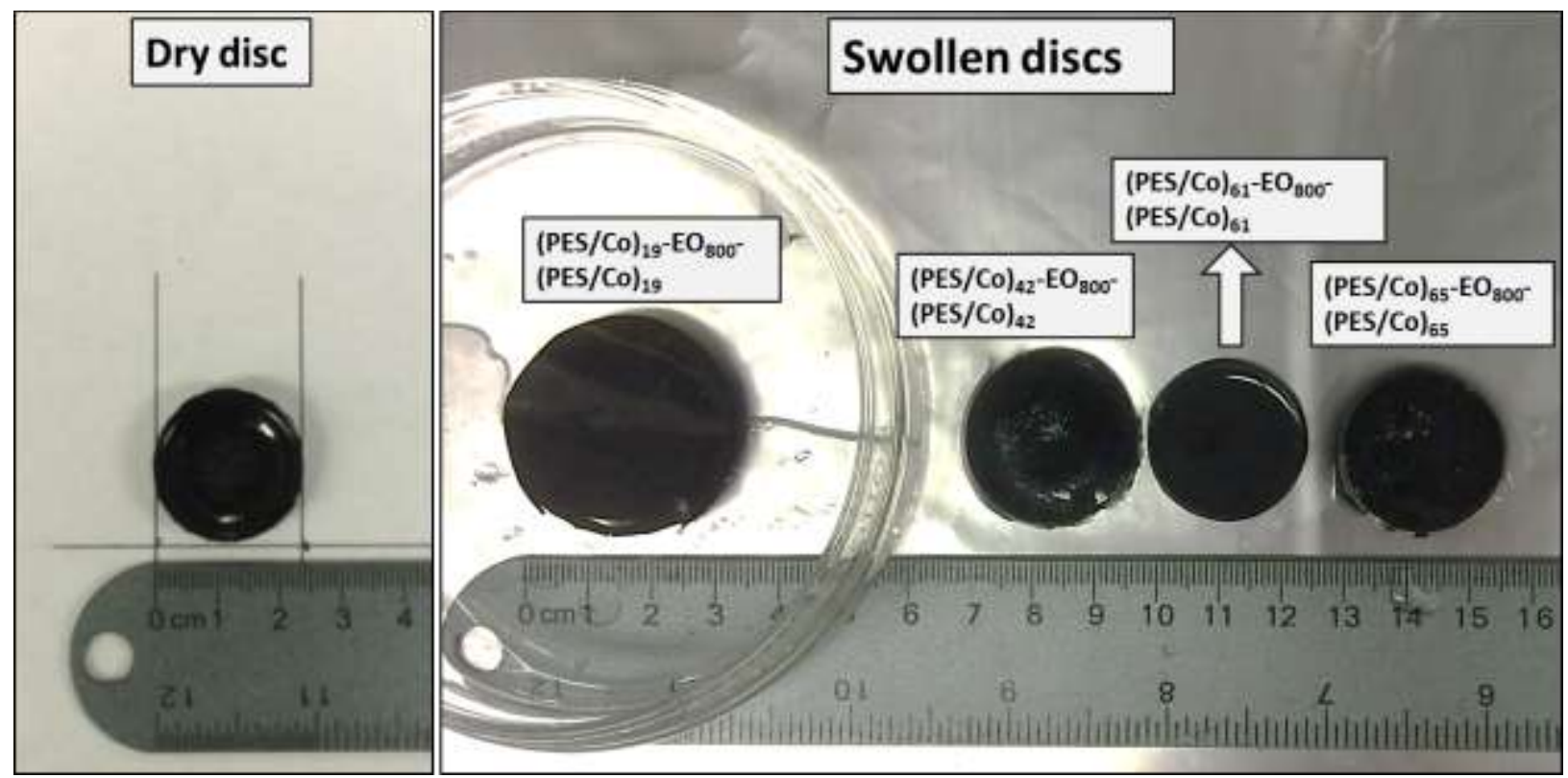

Figure S25. Photos of water-swollen sample discs (PES/Co) ${ }_{19}-\mathrm{EO}_{800}-(\mathrm{PES} / \mathrm{Co})_{19}$, $(\mathrm{PES} / \mathrm{Co})_{42^{-}}$ $\mathrm{EO}_{800}-(\mathrm{PES} / \mathrm{Co})_{42},(\mathrm{PES} / \mathrm{Co})_{61}-\mathrm{EO}_{800}-(\mathrm{PES} / \mathrm{Co})_{61}$, and $(\mathrm{PES} / \mathrm{Co})_{65}-\mathrm{EO}_{800}-(\mathrm{PES} / \mathrm{Co})_{65}$, compared at same scale with a non-swollen disc (initially all discs were $24 \mathrm{~mm}$ in diameter). The puckered $(\mathrm{PES} / \mathrm{Co})_{19}-\mathrm{EO}_{800}-(\mathrm{PES} / \mathrm{Co})_{19}$ disc was gently flattened under a watch glass for comparison to the other samples. 


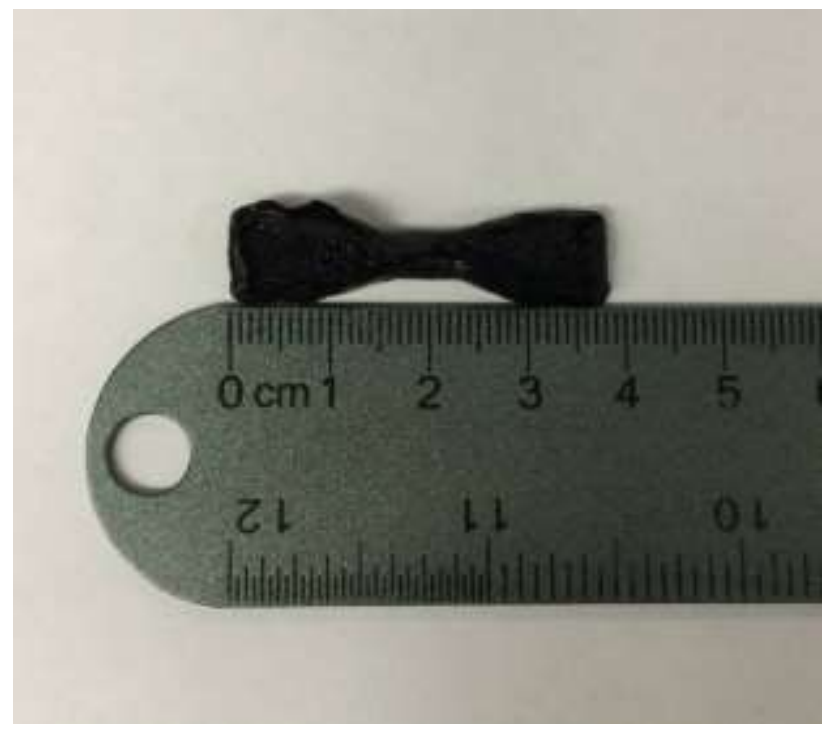

Figure S26. A dumbbell-shaped bar of (PES/Co $)_{19}-\mathrm{EO}_{800}-(\mathrm{PES} / \mathrm{Co})_{19}$ prepared by drop-casting from chloroform. 


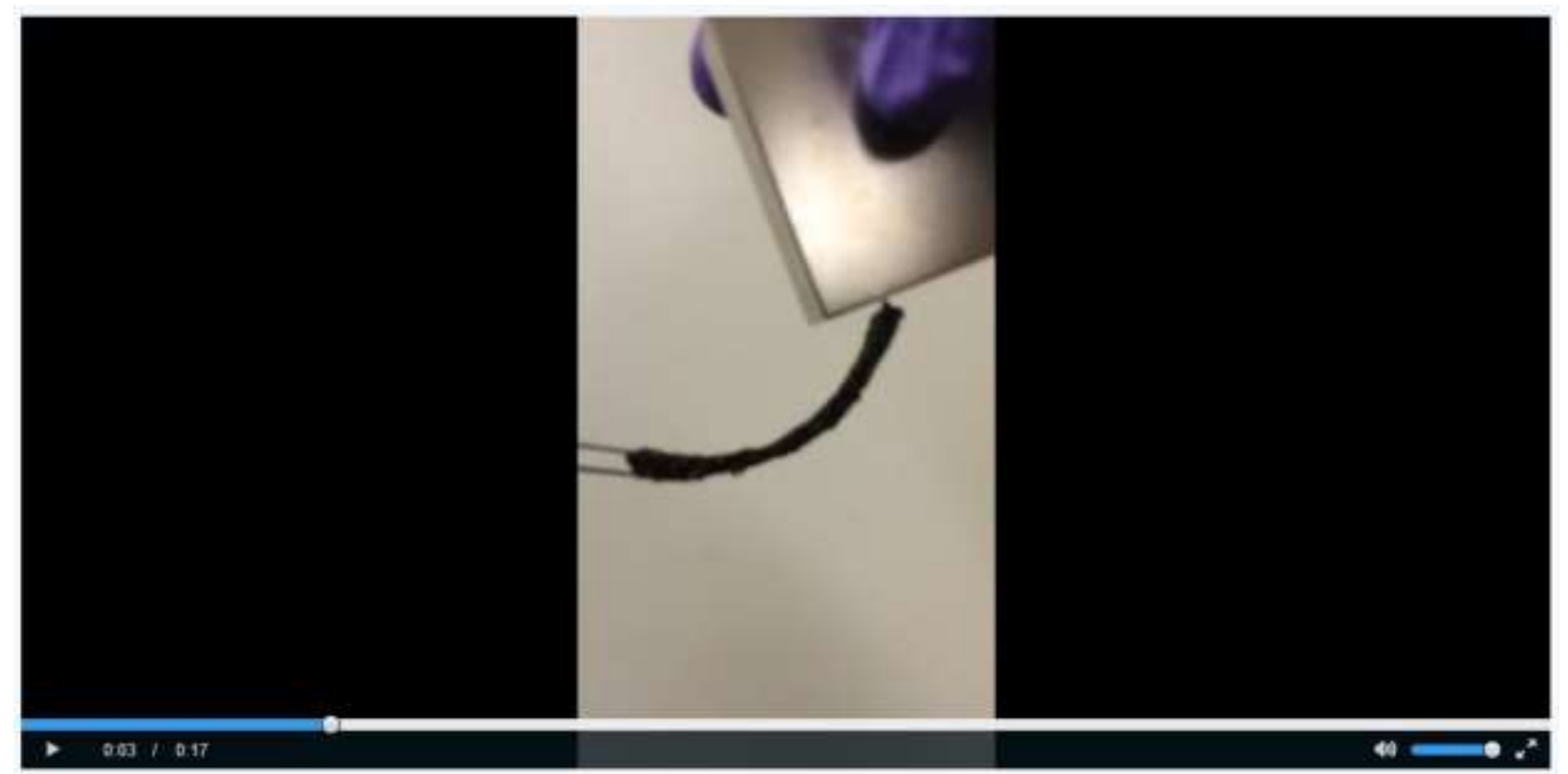

Video S2. A hydrogel bar cast, heated and swollen from (PES/Co $)_{19}-\mathrm{EO}_{800}-(\mathrm{PES} / \mathrm{Co})_{19}$ can be bent by a neodymium magnet. Ctrl+click the image to view the video or go to the following address:

https://www.dropbox.com/s/bywx87jb7g9rf8m/horizontal-bestmovie.mov?dl=0 


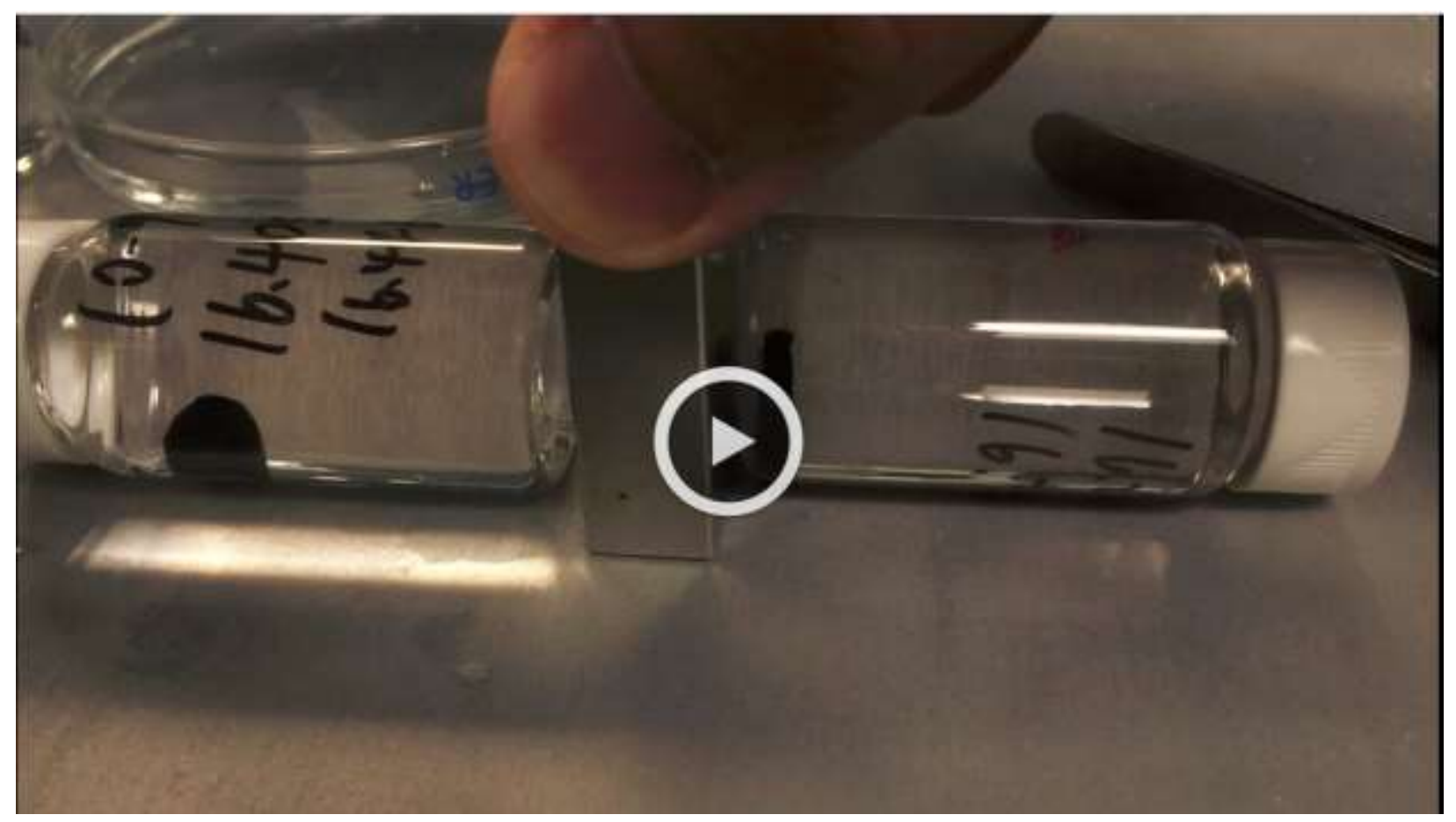

Video S3. Videos for hydrogel discs formed by $(\mathrm{PES} / \mathrm{Co})_{61}-\mathrm{EO}_{800^{-}}(\mathrm{PES} / \mathrm{Co})_{61}$ and $(\mathrm{PES} / \mathrm{Co})_{65^{-}}$ $\mathrm{EO}_{800}-(\mathrm{PES} / \mathrm{Co})_{65}$, both swollen discs can be attracted by a magnet. Ctrl+click to view the video, or open the following address with your web-browser:

https://www.dropbox.com/s/3zz19f0yarze0zO/PPES61Co-PEO800PPES61Co\%20and\%20PPES65Co-PEO800-

PPES65Co\%20swelled\%20magnetism\%20together.mov?dl=0 


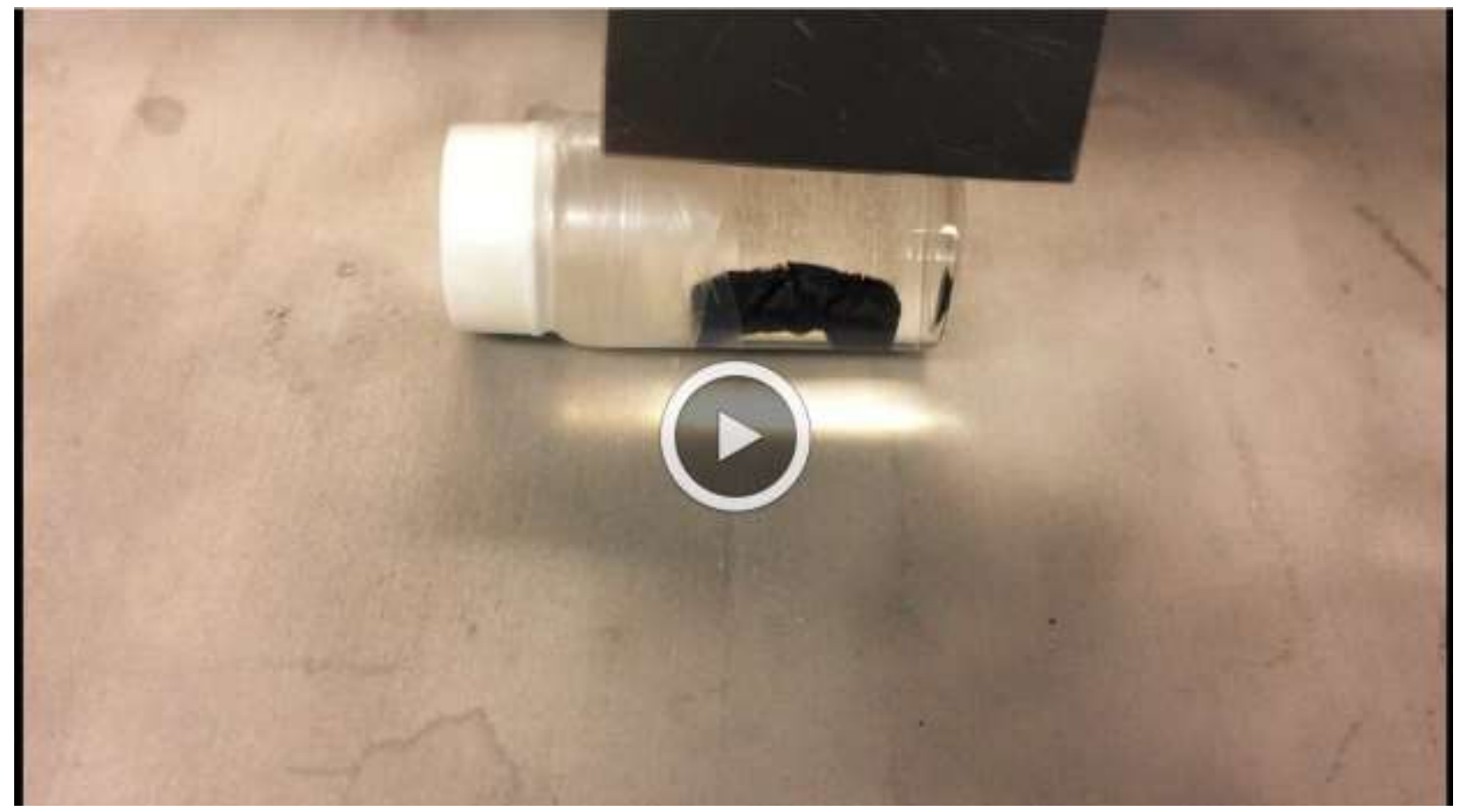

Video S4. A hydrogel bar formed by $(\mathrm{PES} / \mathrm{Co})_{42}-\mathrm{EO}_{800}-(\mathrm{PES} / \mathrm{Co})_{42}$ after soaking in water for 3 months still retains its magnetism. Ctrl+click to view the video, or open the following address with your web-browser:

https://www.dropbox.com/s/i98aiqls4kywfas/2015-08-04\%2016.16.31.mov?dl=0

\section{References}

1. Jiang, B.; Nykypanchuk, D.; Endoh, M. K.; Chen, X.; Qian, B.; Kisslinger, K.; Koga, T.; Parise, J. B.; Grubbs, R. B. Macromolecules 2016, 49, 853-865. doi: 10.1021/acs.macromol.5b02515. 